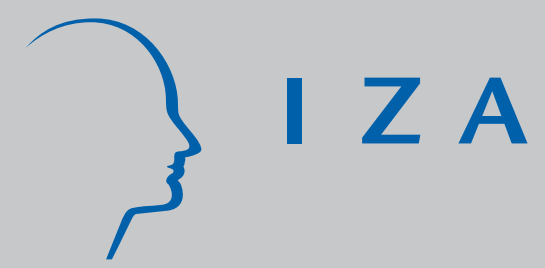

IZA DP No. 7408

Gender Differences in the Effects of Vocational Training: Constraints on Women and Drop-Out Behavior

Yoonyoung Cho

Davie Kalomba

Ahmed Mushfiq Mobarak

Victor Orozco

May 2013 


\title{
Gender Differences in the Effects of Vocational Training: Constraints on Women and Drop-Out Behavior
}

\author{
Yoonyoung Cho \\ World Bank and IZA \\ Davie Kalomba \\ Malawi National AIDS Commission \\ Ahmed Mushfiq Mobarak \\ Yale University \\ Victor Orozco \\ World Bank
}

Discussion Paper No. 7408

May 2013

IZA

P.O. Box 7240

53072 Bonn

Germany

Phone: +49-228-3894-0

Fax: +49-228-3894-180

E-mail: iza@iza.org

Any opinions expressed here are those of the author(s) and not those of IZA. Research published in this series may include views on policy, but the institute itself takes no institutional policy positions. The IZA research network is committed to the IZA Guiding Principles of Research Integrity.

The Institute for the Study of Labor (IZA) in Bonn is a local and virtual international research center and a place of communication between science, politics and business. IZA is an independent nonprofit organization supported by Deutsche Post Foundation. The center is associated with the University of Bonn and offers a stimulating research environment through its international network, workshops and conferences, data service, project support, research visits and doctoral program. IZA engages in (i) original and internationally competitive research in all fields of labor economics, (ii) development of policy concepts, and (iii) dissemination of research results and concepts to the interested public.

IZA Discussion Papers often represent preliminary work and are circulated to encourage discussion. Citation of such a paper should account for its provisional character. A revised version may be available directly from the author. 


\section{ABSTRACT}

\section{Gender Differences in the Effects of Vocational Training: Constraints on Women and Drop-Out Behavior ${ }^{\star}$}

We provide experimental evidence on the effects of vocational and entrepreneurial training for Malawian youth, in an environment where access to schooling and formal sector employment is extremely low. We track a large fraction of program drop-outs - a common phenomenon in the training evaluation literature - and this allows us to examine the determinants and consequences of drop-out and how it mediates the effects of such programs. We find that women make decisions in a more constrained environment, and their participation affected by family obligations. Participation is more expensive for them, resulting in worse training experience. The training results in skills development, continued investment in human capital, and improved well-being, with more positive effects for men, but no improvements in labor market outcomes in the short run.

JEL Classification: $\quad$ O15, J24, I15

Keywords: $\quad$ apprenticeship training, vulnerable youth, gender, drop-outs, Malawi

Corresponding author:

Yoonyoung Cho

World Bank

1818 H Street NW

Washington, DC 20433

USA

E-mail: ycho1@worldbank.org

\footnotetext{
* The authors thank Sangeeta Raja, Rachel Hoy, Maria Jones, Sylvan Herskowitz, Clara Hopler, Emmanuel Kanike, Pavel Luengas, Julia Brown, and Tatyana Zelenska for their excellent work that made this evaluation possible. We thank the World Bank's Spanish Impact Evaluation Fund, Youth Employment Network, and the UK Department for International Development for financial support for the research. The intervention was funded by the Global Fund. The views expressed herein are those of the authors and should not be attributed to the World Bank, its executive directors, or the countries they represent.
} 


\section{Introduction}

Providing young people with opportunities for skills acquisition is widely perceived to be a fair and effective use of public resources. Job training programs have therefore emerged as an important - and widely studied - class of social policy experiments. Due to data availability, however, evaluations of such programs have been limited mostly to developed countries (e.g. Lynch 1992; Bartel 1995; Heckman, Lochner, and Taber 1998; Frazis and Loewenstein 2005; Kluve 2010). Most evaluations rely on non-experimental techniques, including conditioning on observables to limit selection bias (Friedlander, Greenberg, and Robins 1997; Heckman et al. 2000), parametric selection correction methods (Heckman et al. 1998), and propensity score matching and duration analysis (Bring and Carling 2000; Gerfin and Lechner 2002; Sianesi 2004; Chong and Galdo 2006; Biewen et al. 2007; Jespersen, Munch, and Skipper 2008).

This paper reports the results of a randomized controlled trial to evaluate an entrepreneurship and vocational training program for youth in Malawi. Over 80 percent of the workforce in Sub-Saharan Africa is engaged in self-employment in small businesses and household enterprises (Gindling and Newhouse 2012), which makes entrepreneurship and vocational training more relevant in this context than formal job training programs. In Banerjee and Duflo's (2007) 18country-sample-based description of the lives of the poor, they report that a "large fraction of the poor act as entrepreneurs" and are self-employed, with many operating non-agricultural businesses. In contrast, formal employment opportunities are scarce in the developing world (The World Bank 2012b).

The program we evaluate was designed to provide apprenticeship rather than classroom-based training. It targeted young people aged 15-24, because the youth often lack the formal education or skills required to access salaried employment. A growing number of development aid agencies around the world 
have attempted to reduce youth unemployment through on-the-job training and vocational programs. Programs in Tanzania, South Korea, and Indonesia, for example, have attempted to shift secondary school curricula away from general education and towards vocational training (Newhouse and Suryadarma 2011). In the Malawi program we evaluate, 1900 youths from 28 districts received on-thejob training through placement as apprentices to master craftspeople in their area of interest, and the program timing was randomized. Apprenticeships of this type are common in Sub-Saharan Africa, as a way for youth without access to formal education to gain employable skills (Biavaschi et al. 2012). Despite their popularity, virtually no evidence exists on the effects of such programs on participants.

This paper makes three distinct contributions to the literature. First, experimental evaluations of training programs are scarce, particularly for developing countries. ${ }^{2}$ To our knowledge, only three recent studies conduct randomized evaluations in a developing country context. ${ }^{3}$ Card et al. (2011) and Attanasio et al. (2011) explore the impacts of training programs for youth in the Dominican Republic and Colombia (respectively), which had both classroom and on-the-job training components. Attanasio et al. find fairly large effects on probability of employment and wages, while Card et al. find no effect on employment, and modest effects on earnings. These studies were conducted in

\footnotetext{
${ }^{1}$ The ILO (2012) provides an extensive review of qualitative and quantitative studies of informal apprenticeship programs. Monk et al. (2008), working in Ghana with descriptive data, find that returns to informal apprenticeships are high for those who have low levels of education, but fall as formal education increases. We are unaware of any experimental evidence on apprenticeships.

${ }^{2}$ Roughly $10 \%$ of evaluations in the developed world have made use of randomized controlled trial methodology (Card, Kluve, and Weber 2010).

${ }^{3}$ A related (although recent and largely unpublished) literature deals with the returns to business training and financial literacy; however these trainings are designed to deliver generic business skills, rather than trade-specific skills. See Cole et al. (2011), Bruhn \& Zia (2011), de Mel et al. (2011), Drexler et al. (2011), Karlan \& Valdivia (2011), and Calderon et al. (2013).
} 
middle-income countries with larger formal sectors, and the programs targeted wage employment. Our study concerns on-the-job development of technical skills in an environment where self-employment, rather than wage employment, is the norm. Blattman et al. (2012) find that youth given a cash transfer in Uganda invest in vocational training and tools, which then translate into higher levels of employment and earnings.

A second important contribution of this paper lies in our treatment and analysis of program drop-outs. Several published evaluations of job training programs report that a large fraction of beneficiaries randomly assigned to receive training fail to show up, or discontinue training after a short period, and this complicates the evaluation method. Heckman et al. (2000), reviewing five different experimental evaluations of employment and training programs in the U.S., report rates of drop-out as high as 79\%. The Card et al. (2011) Dominican Republic study reports that $17 \%$ of their treatment group failed to attend training, and that follow-up data was not collected on these people. This can introduce a significant selection bias, which complicates the estimation of the treatment effect even for studies which start out with experimental data. ${ }^{4}$

In our Malawi study, we experience similarly high rates of drop-out among youth randomly assigned to receive training, but we anticipated the problem and tracked down a significant fraction of the drop-outs in our follow-up surveys. This allows us to report intent-to-treat and treatment-on-treated results (accounting for the drop-out decision) that are closer to the pure experimental estimates. The main effects if training we report - which are large, significant increases in the self-reported skills and knowledge that the training was meant to

${ }^{4}$ A large body of literature has devised non-experimental methods to correct for these biases (see: Manski 1989; Manski 1990; Horowitz and Manski 1998; Heckman, Lalonde, and Smith 1999; Heckman et al. 2000; Horowitz and Manski 2000; DiNardo, McCrary, and Sanbonmatsu 2006; Lee 2009). 
impart, and improvements in trainees' subjective measures of well-being - are not sensitive to the way drop-outs are handled.

More importantly, we conduct a detailed analysis of why trainees chose to drop out. Since dropping out is a commonly observed phenomenon across such programs in both developing and developed nations, it is useful to identify its causes and consequences, in order to better understand the direction of bias in existing evaluations of training programs stemming from this specific source of attrition. Our data allow us to characterize whether drop-outs in training are positively or negatively selected. Why potential participants drop out and do not take advantage of a program designed to build their human capital, and offered to them at deeply discounted rates (or even for free) is an important puzzle worth exploring. ${ }^{5}$ We collect data on alternative opportunities and unanticipated shocks around the time of program inception to understand better the conditions under which people choose to not partake in training.

These opportunities and constraints happen to affect men and women differently, which leads to the third main contribution of this paper: developing a better understanding of why training programs may have heterogeneous effects across gender. A growing literature documents differential treatment effects by gender (e.g. see Bergemann and van den Berg 2008; Attanasio, Kugler, and Meghir 2011; Blattman, Fiala, and Martinez 2012). We find generally better training outcomes for men compared to women. While improvements in selfreported skills were similar across genders, male trainees exhibit greater improvement in subjective measures of well-being and confidence compared to

\footnotetext{
${ }^{5}$ This is related to a literature that identifies technologies designed to meet pressing needs are often not adopted at rates commensurate with their potential benefits (Meredith et al. 2011; Miller and Mobarak 2012). The case of training appears related to a literature that suggests that the low take-up may signal that the product or service does not work as well as anticipated, given local conditions. (e.g. see Miguel and Kremer 2004; Ashraf, Giné, and Karlan 2009; Duflo, Greenstone, and Hanna 2012; Mobarak and Rosenzweig 2012).
} 
women. Any negative outcomes of treatment we observe tend to be associated with women - reduced savings and decreased earnings-related activities following treatment.

These differences are explained by both the conditions under which women participate in training, as well as gender differences in the training experience. First, women drop out due to adverse shocks (severe illness or injury), and are more likely to participate when alternative opportunities disappear (e.g. they get fired). Men's participation decisions are not affected by adverse external conditions. Girls are on average less educated than boys at baseline, have more dependents, and spend more time on domestic chores as opposed to paid labor or business activities. Women (but not men) self-report constraints such as 'family obligations' and 'getting married' as the main reasons they drop out. Second, participating in training is expensive and trainees - especially girls have to draw down their savings to do so. This is partly due to differences in the training experience: men are more likely to have received financial support from trainers or master-craftspersons (MCs) during the training. Distance to the training facility is more of a constraint for girls, boys are also more likely to attend regularly, and three times as likely to receive a paid job offer from the MC following the training period. Overall, the results suggest that women are significantly more constrained in their decision-making, which lead to a worse training experience, less support, and ultimately results in worse training outcomes. These results shed light on the more stringent constraints under which poor girls have to make decisions in developing countries, and how these inhibit skill acquisition. 


\section{Context and Experimental Design}

\subsection{Background}

Malawi is one of the world's poorest countries. Over $50 \%$ of the population falls below the national poverty line, while GNI per capita is just \$360 (The World Bank 2012a). Unemployment among youth is high (9.6\% for women, $8.5 \%$ for men) (International Labour Organization 2011). Levels of formal education are low, as about $58 \%$ of students drop out after primary school (Aggarwal, Hofmann, and Phiri 2010). Most youth rely on low-productivity subsistence agriculture or self-employment to sustain themselves and their families. Youth are particularly vulnerable as they often possess fewer productive alternatives.

To address the employability issues, promote productive self-employment and reduce vulnerability to risky sexual behavior, in 2009 the Government of Malawi decided to pilot a new apprenticeship program aimed at vulnerable youth. The program was implemented by the Technical Education and Vocational Education and Training Authority (TEVETA) across all 28 districts of Malawi. The program was targeted to vulnerable youth, mainly defined as orphans or school dropouts. The geographic scope of the program made data collection more expensive, but it allowed us to evaluate the program based on a nationally representative sample of vulnerable youth.

Baseline results (see Table 1) show that the selection process was successful in choosing participants who were vulnerable and poor. More than a third are orphans of both parents, over 60 percent live in a dwelling that has a grass roof (a proxy measure for poverty), and over 80 percent report skipping a meal "often" or "sometimes" due to lack of money. Around two-thirds of the participants were male. They were 21 years old on average, and $10 \%$ were still in school. When compared to a nationally representative sample of Malawian youth aged 15-24 from the Malawi Third Integrated Household Survey (National 
Statistical Office 2011), youth in our sample are more likely to live in a house with a grass roof, more than three times as likely to be an orphan, and less likely to still be in school.

TEVETA then identified a pool of potential trainers in each district. The MCs (master craftspeople) were selected from this pool based on their expertise and business performance in the neighborhood. MCs were compensated for their work, and benefited from the free labor that the apprenticeship program brought. In the 23 districts where our survey took place, there were $164 \mathrm{MCs}$ that offered 17 different trades. Each had an average of 14 years of practical experience in their specific field. TEVETA created a set of training modules customized for each of the principal trades, and provided a one-day training to the MCs on how to use these modules.

During the apprenticeship, each MC trained between 1 and 8 trainees at their workshops. MCs' workshops tend to be located in urban areas, while many of the many of the trainees lived in rural areas. The trainees were responsible for finding their own accommodations near the workshop, but received a small stipend (about $4300 \mathrm{MWK}$, approximately US\$28) to cover meals and accommodation.

\subsection{Experimental Design}

The evaluation used an experimental phase-in design. Participants were randomly assigned to two cohorts, a treatment group that started the program immediately, and a control group that started the program around 4 months later on average, right around the time of the follow-up survey. We are therefore able to report short-run effects of training. Two thirds of the 1,900 eligible youth were assigned to treatment and the remaining third to the control group.

The baseline survey was collected in March-April 2010 on a random subset of the youth selected. We surveyed 1,122 individuals of the original 1,900, 
of whom 363 were in the control group and 759 were in the treatment group (see Figure 1). Summary statistics from the baseline survey indicate that randomization was successful in achieving balance across treatment and control groups (Table 1).

Trainees reported to training between August 2010 and May 2011; the specific start date varied by district and by MC. Training lasted for three months on average, but varied depending on the type of skill being taught. Table 2 provides the breakdown of occupations by gender of trainees.

The follow-up survey was conducted in June-August, 2011. The follow-up survey included questions on time use, employment, psychological well-being, risky sexual behavior, and trainee assessments of training quality. In order to increase the sample size, we returned to the original pool of 1,900 youth who had been selected to participate in the study. The sample at follow-up is composed of the 755 baseline respondents who we were able to find at the time of follow-up, plus 274 new participants (181 treatment, 93 control), for a total of 1,029 respondents.

In addition, we surveyed all MCs regarding their experience as trainers and their perception of each of the trainees' skills, diligence, effort, attendance, and so on. Finally, we also conducted a brief qualitative survey with the implementing agency's desk officers regarding their experience with the intervention to inform future program design.

\subsection{Attrition and Drop-out}

Like many development programs, the TEVETA program suffered from several administrative setbacks which affected the implementation of the program. For example, between the time that the original 1,900 youth were selected and the time that the baseline survey was conducted and the treatment participants were invited to begin training, over a year went by. Thus at the time that the training 
was offered, about $9 \%$ of the people invited to training chose not to participate (we explore the possible reasons - including other potential opportunities or barriers facing these people - in greater depth below). In addition, owing to administrative errors, a large number (about 30\%) of those who were supposed to be invited to participate in the training report in our follow-up that they never received the invitation. Lastly, even among those who were invited to the training and who chose to participate, not all completed the training. We treat all of these (not invited, did not participate, or did not complete) as drop-outs (as labeled in Figure 1), as they were assigned to treatment but did not participate. For analysis purposes, however, we distinguish between those who dropped out because of the administrative error (not invited) and those who chose to drop out. More than half of all people who dropped out did so due to the administrative error.

In addition to people who dropped out of the training, there was also survey attrition between the baseline and follow-up surveys. Specifically, about $1 / 3$ of the respondents in the baseline survey could not be found for the follow-up survey (242 from the treatment group, and 125 from the control group). This poses identification issues, since attrition from the survey is correlated with participating in training, and therefore with our outcome variables. People who participated in training were very easy for us to track since we conducted our follow-up survey very soon after the completion of training. Thus it is likely that, of the attriters in the treatment group, most are drop-outs. This attrition is particularly problematic if we only successfully tracked a non-random sample of the drop-outs. In Table 3a, we examine whether the attriters are statistically different from the drop-outs who we were able to track in terms of their baseline characteristics. It is encouraging to note that the two groups are statistically similar across most dimensions, which indicates that our extra efforts in tracking drop-outs may have reduced some of the selection bias introduced by non-random attrition. This is especially true when we restrict our attention to drop-outs who 
chose to stop participating (and not the administrative errors). It appears that TEVETA ultimately chose to not invite a few participants who were originally selected but turn out to be relatively rich. They may have been correcting an earlier administrative oversight in selecting an ineligible participant (since the program was designed to target the most vulnerable youth). However, even after these corrections, the attriters are older, have more dependents, and are less likely to be currently enrolled in school. In our analyses, we report evaluation results controlling for these baseline differences. We also conduct a bounding exercise, which confirms the direction of our results within a range of possible values for the missing observations.

It is crucial to investigate whether individuals assigned to treatment versus control group attrite at different rates since such voluntary exit can threaten the validity of our randomized design. In Table 3b, we estimate a linear probability model where attrition is a function of initial randomized assignment to receive training. The results indicate that there is no relationship between initial assignment to training and the likelihood of continuing in the sample. The coefficient on "Assigned to Treatment" is -0.017 , with a standard error of 0.025 . When we break up the sample by gender, treatment assignment is completely irrelevant for men in their likelihood of attrition (a coefficient of 0.000 ), but it is relevant for women (coefficient of -0.082 , but not statistically significant at conventional levels). We will therefore present results separately by gender throughout the paper, and attrition bias will be a bigger concern in the female sample. This also provides the first indication that girls and boys appear to make training participation decisions under a different set of conditions.

\section{Determinants of dropping out}

The rates of program drop-out were clearly very high, both because of administrative errors by the implementers, and because some trainees chose not to 
attend or complete the program. We tracked down many of the drop-outs, and collected data on adverse shocks and new opportunities that potential trainees faced in the period prior to program inception for the entire follow-up sample, in order to identify the determinants of drop-out. Although drop-outs are a common phenomenon in training programs and a challenge to evaluation studies, this study is one of the few to have extensive data on drop-outs and the conditions they faced. Examining whether people are forced to leave the program due to external factors like unanticipated adverse shocks or choose to leave to take advantage of better opportunities will inform future program design. It also serves to shed light on the direction of bias associated with ignoring drop-outs when follow-up data on them are missing. In our case, having follow-up data on a large fraction of drop-outs means that we can get closer to reporting pure experimental (intent-totreat) estimates of training program effects.

Drop-out rates varied a little across occupations in which training was offered. Almost a third of all participants invited to training for auto mechanic jobs chose not to complete. Drop-out rates were lowest $(16 \%-20 \%)$ in beautycare, electronics, metalwork and construction (Table 4).

Table 5 examines the determinants of drop-out. Specifically, we estimate a linear probability model using the sample of individuals assigned to treatment where the dependent variable is an indicator for not completing training. We use two definitions of drop-outs. The first definition includes those who report that they were never invited to training, and the second definition excludes them, in order to focus on the trainees' decisions to not attend training sessions. The equations are estimated separately for males and females.

The location, accessibility, and convenience of the training sessions, as well as family support appear to be important determinants of attendance. Having friends or relatives close to the training center is a very strong predictor of whether trainees - both males and females - can complete training. Compared to 
males, females are more likely to drop out due to severe illness or injury, or if they live far away from the training center. In contrast, boys drop out in order to take advantage of migration work opportunities (ignoring drop-outs due to administrative error).

In general, female participation appears to be much more sensitive to external constraints imposed on them compared to their male counterparts. Not only do females drop out more due to distance, illness or injury, but on the flip side, females who are fired from a job are more likely to complete the program. In other words, they stick with the program in cases where alternative opportunities disappear. These same variables do not have a significant effect on the drop-out propensity of male trainees. The gender difference in drop-out patterns mirrors the findings from the analysis of attrition, in that selection concerns are more significant for women.

\section{Estimation of Program Effects}

\subsection{Outcome Measures}

Vocational training may improve labor market outcomes through multiple channels. First, training imparts practical, technical skills, which increase trainees' human capital, and potentially their productivity. Second, training sessions may increase awareness of higher-paying job opportunities, and improve knowledge of how to access these jobs and how to connect to potential employers. Working directly with the MCs, the workers will be able to connect not only to one potential employer but potentially to the network of employers through recommendations. ${ }^{8}$ Third, practical training under MCs' mentorship allows trainees to reveal their "type" (effort, skills and talents) to a potential employer.

\footnotetext{
${ }^{8}$ See Owolabi and Pal (2011).
} 
Fourth, training may also impart more general skills on how to start and operate a business, which could spur entrepreneurship. Therefore, either salaried employment or self-employment may increase due to training.

An additional consequence of participation in training may be increased human capital investment, beyond the duration of the training program. Trainees may learn about the importance of investing in skill development to further improve their labor market prospects. We will therefore estimate the effects of training on time use: hours worked in paid labor and self-employment (on family farm or self-employed), and also hours devoted to human capital investment beyond the training period. We will also measure downstream outcomes such as earnings, total expenditures (as a proxy for income), business start-up, and migration.

We also examine the effects of training on self-reported (subjective) outcomes related to the skills that the vocational training program were meant to impart to study whether (a) the training program achieved its intended objectives focusing on skills and labor market outcomes, and (b) whether psycho-social well-being of participants improved as a result.

\subsection{Estimating Equations}

Randomizing the offer to attend the training allows us to overcome the selection bias into training. We will report both the effect of offering the training based on random assignment (intent-to-treat estimates), and the effect of receiving training among those who actually participated in the training, with participation instrumented by the random assignment. The discrepancy between random assignment and program participation is almost entirely due to drop-outs (control group individuals did not have any opportunity to participate in training). Tracking down a large fraction of the drop-outs therefore allows us to report estimates closer to the pure experimental estimates. 
The estimating equation for the intent-to-treat estimate is:

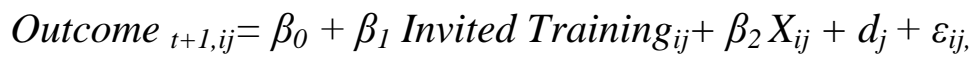

where Outcome ${ }_{t+1, i j}$ are a set of outcomes of interest for an individual $i$ in district $j$ at the follow-up $(t+1)$ and $d_{j}$ captures time-invariant district-level characteristics; $\varepsilon_{i j}$ is the error term. The estimated coefficient $\beta_{l}$ captures the effect of the random assignment, or being offered to attend the training. In some specifications we include a set of fixed individual and household characteristics $X_{i j}$ to increase the precision of the estimates. These control variables include household size (squared), number of children under 18, acres of land owned, age, gender, and indicator variables for whether the respondent is married, if he/she is currently a student, if he/she has friends or family living close to the training site, and whether a household member who was contributing to household income died in the past 12 months.

The effect of training for those who attended the training is estimated using IV techniques, where the random assignment to treatment, Invited Training is used as an instrument for the indicator variable Attended Training $_{i j}(=1$ if the individual attended the training) ${ }^{9}$ in a first stage:

$$
\begin{aligned}
& \text { Outcome }_{t+1, i j}=\alpha_{0}+\alpha_{1} \text { Attended Training }_{i j}+\alpha_{2} X_{i j}+d_{j}+v_{i j} \\
& \text { Attended Training }_{i j}=\gamma_{0}+\gamma_{1} \text { Invited Training }_{i j}+\gamma_{2} X_{i j}+d_{j}+\omega \omega_{i j},
\end{aligned}
$$

\footnotetext{
${ }^{9}$ Attended Training $_{i j}$ is defined by self report of trainees. To be considered to have attended training, trainees must (1) have received the invitation to training, (2) state that they participated, (3) state that they participated for at least one month, and (4) state that they rarely or never missed training days. We also ran an alternative specification in which the dependent variable is one if the person was (1) assigned to treatment and (2) not listed as a drop-out in administrative records. However, there is considerable discrepancy in the administrative reports of who did or did not drop out, and this variable also does not catch non-compliers in the control group (of which there were 4) who managed to attend training despite not being selected for it. The results from the two specifications are similar, and we prefer the former specification.
} 
The estimate of $\alpha_{1}(2 \mathrm{a})$ yields the local average treatment effect of the training i.e, effect for those who was induced to attend the training as a result of random assignment to participate. Since the invitations were randomly assigned, the IV estimate can be interpreted as the causal effect of the treatment among compliers.

\section{Results}

\subsection{Effects of Training on Skill Development and Human Capital}

We first investigate whether the training achieved its primary objectiveboosting skills that the training was meant to impart, according to the trainees' own assessment. Specifically, we focus on the following proxies for skill development: (i) self-assessment of skills in a particular trade (estimated on the scale from 1 to 10); (ii) knowledge of how to calculate profits; (iii) An indicator that the individual knows how to start a business (self-assessed). Both intent-totreat and the IV estimates of the training participation presented in Table 6 indicate that the training was very successful in improving the self-assessed practical skills of the young people in our sample.

Assignment to treatment (ITT estimate) increases self-assessed skill score in a specific area of expertise by 2.6 points on a 10-point scale, or 1.1 points when district dummies and baseline control variables are added. The mean value for this variable is 2.6 in the control group, so the effect of training represents a substantial increase. We also observe positive and strongly significant effects of training on the other two self-assessed categories of skill development. Being invited to the training increases the subjective business-profit-calculation ability by $37 \%$ of control group mean (or $14 \%$ with district dummies and baseline controls). Training also increases the likelihood that a respondent knows how to start a business by 24 percentage points (or 9 percentage points with controls, representing a 20 percent increase from the mean in the control group). 
There are two important further points to note from Table 6. First, IV estimates where training participation is instrumented by the random assignment to training are always larger than the intent-to-treat estimates, which is expected, since almost all non-compliers are drop-outs from the treatment group. Second, controlling for district dummies only does not affect the magnitude or statistical significance very much, but adding controls for individual/household characteristics that were related to the drop-out decision and imbalance at baseline does compress the magnitude of treatment effects. We will therefore report this conservative specification alongside the pure experimental estimates in all subsequent tables.

\subsection{Time Use During and After Training, and Economic Outcomes}

Table 7 examines another first-order effect: how training changed the participants' time use relative to the control group during and immediately after training. We examine outcomes at four distinct points in time: a) month before the training (as a placebo outcome); b) the period during training; c) month after the training; and d) a week before the follow-up survey (which was, on average, 4 months after completion of training). Constructing time periods this way in our follow-up survey allows us to measure time use consistently among respondents engaged in a variety of activities (training in different sectors, and then either working, studying, or self-employed). An important drawback is that the survey timing does not allow us to capture the longer run effects of training. Card et al. (2010) and Cho and Honorati (2013) argue that it probably takes longer for labor market effects to materialize.

Table 7 presents ITT and IV results on (i) hours worked in paid labor (which includes any paid employment, including paid labor in agriculture); (ii) hours worked in self-employment, which includes both work on family-owned land and in own business; and (iii) hours spent in human capital development 
such as school, job or trade training for each of the time periods (before, during, after training) described above. Reassuringly, there are no statistically significant effects of treatment assignment on time use in the month prior to training (the placebo outcome). Treatment assignment and training participation leads to very large increases in time spent on human capital development (i.e., training) during the training period. Being assigned to the treatment group leads to 170-343 extra hours of training, and those who actually attended invested an extra 636-773 hours in training according to IV estimates. Since training in most professions lasted over three months (the average training duration was 13-14 weeks), this is a reasonable estimate, and suggests that the training kept all trainees quite busy over the entire training period.

Investing all this time in training displaced many hours of work in both paid labor and in self-employment (e.g. decreases of 32 hours and 76 hours respectively in the ITT estimate). Both the IV and ITT estimates suggest that about $30 \%$ of the hours in training came from displacing paid labor and self employment hours. This is an important result because it shows that the opportunity cost of attending the training in terms of both time and forgone earnings may be substantial. This may explain some of the drop-out decisions, which we will explore more in our gender-disaggregated analysis. On the other hand, $70 \%$ of the training hours are for youth who would otherwise be unemployed, under-employed, in school, or enjoying leisure during the training period.

Turning our attention to the effects of treatment assignment on time use after the training is completed, we see that the most important consequence of the training program is continued investment in human capital. This is promising, because this may have significant and lasting implications for labor market opportunities in the long run. In some cases, this is because the trainee forms a 
longer-term relationship with the master craftsmen, something we will explore below.

Training participation increases total hours spent on skill development (through school, or other job training) by 6 hours (ITT) or 14-24 hours (IV) one month after the training. This is large relative to how the control group spends their time, and relative to how all individuals spent time prior to the start of training. In the week preceding the survey, those who completed the training program continued to spend 3-6 hours per week in additional human capital development activities. We do not observe strong significant effects in hours worked in the period after training, except for some effect on self-employment that is sensitive to the inclusion of control variables, and therefore not robust.

In Table 8 we see that all this extra time spent on training and on further human capital development post-training comes at a financial cost to the trainees. Trainees have to draw down their savings by $1600-3000$ Kwatcha (US\$10-20) ${ }^{10}$, which is a substantial amount in this sample. Importantly, we will see below that this effect is largely driven by female trainees, who face even more drastic decreases in savings (of about US\$38) in the corresponding specification. Data we will present below on the training experience indicates that the stipend provided for the participants (of $4300 \mathrm{MWK}$, or US\$28 on average) was not sufficient to cover transportation and lodging costs.

Given that we do not find any significant changes in hours worked in the short run, it is not surprising that we also do not find a discernible impact of training on the total earnings (last week) and on total monthly expenditure. The estimated effects are negative, but generally not statistically significant. Consistent with the human capital investment results both during and post

\footnotetext{
${ }^{10}$ The exchange rate used is MWK $1=0.0065$ USD (from http://www.oanda.com/currency/historical-rates/).
} 
training, we also see that training participants were significantly less likely to start a business in the previous 12 months. Trainees are also significantly less likely to migrate away in search of employment, which is again consistent with trainees making some longer-run investments, often in collaboration with the master craftsmen trainer's at their location of origin.

\subsection{Effects of Training on Well-being and Health Behaviors}

In Table 9 we investigate the impacts of training on non-market outcomes including psychosocial well-being, self-esteem, and sexual behavior. Subjective measures of well-being are a useful complement to the time use and labor market data we collect to paint a more comprehensive picture of the overall effects of the training intervention. Such measures are increasingly used in the economics and evaluation literatures (Ashraf, Field, and Lee 2010; Devoto et al. 2012).

Participating in training had strong positive effects on subjective measures of well-being. Specifically, random assignment to training increases the share of respondents happy and satisfied with life and agreeing that life has improved during the last year by 5 and 7 percentage points respectively ( 22 and 29 percentage point effect in the IV - TOT specification). These are sizeable increases relative to the control group means. Additionally, related to the prior discussion on skills acquisition, trainees report being more confident in their ability to switch away from agriculture and earn money in other sectors. We don't observe any statistically significant effects on health behaviors. However, there is important heterogeneity by gender across all these outcome variables, which we will explore below.

\subsection{Gender differences in outcomes}

Both the drop-out and the attrition analysis indicated that women are significantly more constrained in their decision-making than men (unlike men, women 
participate in training when other opportunities disappear, drop out due to illness or injury, and attrite when they are not assigned to treatment). Table 10 reports results disaggregated by gender to explore whether these apparent constraints lead to differential gender incidence of benefits and costs of training. The sub-sample analysis also helps to establish the robustness of our results in the male sample, where attrition bias is less of a concern.

Trained men and women report very similar gains in self-reported skills, but that is where their similarity ends. Men spend more time in training (probably due to the occupations they select into), and this extra time comes from men's hours in self-employment. In the full sample, the only significant treatment effect on time use post-training was that trainees continue to invest in human capital development. The gender-disaggregated results show that this comes entirely from the sample of men. Men spend 11 extra hours (21 hours in TOT) in further skills development in the month after training, continue to do so in the week prior to the survey, and these hours reflect over $100 \%$ increases relative to the control group. Among women, there is no treatment effect on any category of time use in the period after training ends.

Attending training was evidently much more costly for women. They experience a much larger decline in personal savings (of MWK 5600, or US\$36) by participating in training. This extra depletion of personal savings among female participants may indicate that women are more credit constrained and do not have other sources of financing. We will explore this further by examining data on the trainees' experience during the training program. Only women (and not men) experience other statistically significant negative effects of training on employment and business activities. Trained women's earnings are lower and they are less likely to have started a business.

Next, we see that the positive gains to subjective measures of well-being and confidence (that we reported on earlier) accrue to men to a larger extent. This 
is consistent with the heterogeneity in the all the real effects of training across gender, and the extra constraints under which women appear to make participation decisions. Treatment is associated with smaller positive effects in the female sample also, but men are twice as likely to report that "life has improved in the past year". However, the gender difference is not statistically significant.

One positive effect of the vocational training program on women is that they are significant less likely ( 7 percentage points in ITT, 14 percentage points in TOT) to have given birth in the past year. 19 percent of young women in the control group had a child in the past year, so this signifies a very significant decline. Baird et al. (2011) also found that a schooling intervention resulted in delays in childbirth and marriage. Early sexual experience, marriage, and childbirth are often associated with lower investment in education and lower future earnings potential (Baird et al. 2010; Baird, McIntosh, and Özler 2011), so the reduced incidence of childbirth is an encouraging result. The rate of condom use also increases with treatment in the female sample, but this effect is not statistically significant.

Why are the effects of vocational training much more positive for men than they are for women? Is it that the nature of the training, and the way men and women experienced the program was very different? To investigate this further, we analyze:

(a) The details of the training program and the experience as reported by male and female trainees in the treatment group, and

(b) Summary statistics on the baseline conditions faced, to identify whether females were differentially constrained based on their domestic situation.

Overall, males and females report similar experiences during training. Male and female trainees are of similar age, the training programs were of similar 
length on average, they received similar-sized stipends from the implementing organization, and the $\mathrm{MC}$ attendance and mentorship/encouragement were all comparable. However, boys are significantly less likely to have missed any days of training, and they are slightly (10\%) less likely to drop out, although the latter difference is not statistically significant. These suggest - as the drop-out and attrition analysis did before - that women are participating in training in a more constrained environment. These slight gender differences then translate into better "real" experiences for boys: (a) MCs are significantly more likely (by 9 percentage points, or 20\%) to help boys with food and money during the training period, (b) boys are accordingly 4 percentage points (8\%) less likely to report that the (same sized) stipend is insufficient to meet their needs, and (c) boys are significantly more likely to receive paid work from the MCs after the completion of training. Paid employment is a rare outcome, and the 2.8 percentage points greater likelihood of boys receiving that offer from an $\mathrm{MC}$ represents a large (233\%) increase over girls.

In terms of the differential conditions faced by women at baseline before the training is implemented, comparison of summary statistics indicate that women live in households with fewer adults and more dependent children. Women report spending almost twice as much time as men on household and agricultural chores. Men, on the other hand, are older, more likely to be the head of household, and less likely to still be living with at least one parent. They are more likely to have completed secondary school, and they spend more time in paid labor. While both male and female youth of Malawi are burdened with a great deal of family responsibility at a young age, the fact that men's responsibilities appear to be more financial in nature, and more likely to carry market returns, may imply that they have the chance to develop skills outside the home that allow them to make better use of the training. 
In contrast, when we ask dropouts why they had chosen to not participate, it becomes clear that women's responsibilities may prevent them from taking advantage of the training. $21 \%$ of women cited family obligations as the reason, while no men did. This matches reports we received at baseline, where women were twice as likely ( $\mathrm{p}$-value of gender difference $=0.03$ ) to report 'family obligations' as the reason they had never before taken advantage of any training. Women are also seven times as likely to mention getting married as the reason for drop-out ( $\mathrm{p}$-value $=0.02$ ), and four times as likely to mention transportation problem ( $\mathrm{p}$-value $=0.17)$. Men on the other hand are more likely to report administrative errors - that they did not receive the message from TEVETA to show up, possibly because migration rates are greater for men. ${ }^{11}$

In summary, baseline characteristics and the attrition and drop-out analyses indicate that women participate in training in a more constrained environment. They get less financial support which puts greater pressure on their personal funds. Their attendance is slightly worse, drop-out risk is higher, and in turn MCs treat male trainees a little better during and after training (which, admittedly, may be due to gender segregation in the occupational mix rather than any particular MC's behavior). All of this accumulates to worse treatment effects for girls compared to boys, and lower levels of (subjective) satisfaction with life after training.

\footnotetext{
${ }^{11}$ An important caveat to this discussion is that there is segregation in the types of industries/occupations that men and women select into (see Table 2). Around $85 \%$ of training in auto mechanics, metalwork, and construction goes to men, while women are more likely to be trained in clothing fabrication or beauty. Some of these gender differences may reflect underlying differences in employment conditions within these professions. Even so, that would imply that women are selecting into professions that are more constrained or lead to worse outcomes.
} 


\section{Examining Drop-out and Attrition Bias using Follow-up Data on Drop- outs}

The follow-up data we collected on drop-outs yields another strategy to examine whether drop-outs are selected in either a positive or negative direction. If those assigned to training dropped out because better alternative opportunities cropped up (i.e. positive selection), then we would expect the drop-out decision to be associated with better post-training outcomes. We estimate a simple OLS model, separately by gender, in which we compare outcomes for those who chose to drop out with outcomes for those who chose to continue participating in training. The right-hand-side variable is an endogenous choice (to drop out) that is not randomly assigned, and therefore these results cannot strictly be interpreted as causal effects. Nevertheless, the conditional correlations reported in Table 12 are still helpful in identifying the likely direction of bias, if any, associated with dropouts. This is a potentially useful exercise given the high drop-out rates experienced in many training evaluations around the world.

In general, we find that drop-outs - when compared to training participants - seem to have simply missed out on the benefits of training that we estimated by comparing trainees to the control group. In other words, the dropouts look very much like the control group in terms of their follow-up outcomes. Individuals who dropped out have a statistically significantly lower level of skills development, and are significantly less likely to think that their life has improved during last year, perceive themselves as entrepreneurs, or have confidence that they can secure a job outside of farming. These are mirror images of the training effects we have observed in all the main regressions, and even the magnitudes are similar to the main treatment effects. This implies that the outcomes for drop-outs 
are similar to those for the (randomly assigned) control group. ${ }^{12}$ This suggests that drop-outs do not appear to be systematically selected in either a positive or negative direction. To reiterate, the drop-out decision is not randomly assigned, and these results are therefore only suggestive.

Even though we track down many of our dropouts, our sample is still plagued by some survey attrition, and the attriters are almost all either drop-outs or were originally assigned to the control group. Although the results above suggest that the attriters' profiles are unlikely to introduce systematic bias in either direction, we employ a matching and imputation method here to estimate lower bounds for our treatment effects, in order to verify this formally. Specifically, following Calderon et al. (2013), we use one-to-many matching to match both treatment and control attriters (who were surveyed at baseline, but not at follow-up) to 5 members of the control group for whom we have follow up data. ${ }^{13}$ We then replace the missing values of our outcome variables with the average of the matched control respondents. This constitutes a lower bound for our results because it assumes that attriters from the treatment group would have experienced the same outcomes as our controls, thereby minimizing the difference between treatment and control.

Results are presented in Table 13. Overall, the results confirm our original estimates in terms of magnitude and direction. A few differences are worth noting, however. When using the imputed values, ITT estimates show a

${ }^{12}$ Indeed, when we compare summary statistics for the control group with those of the group of drop-outs, controls are slightly older and also marginally more likely to be numerate than dropouts, but otherwise there are no statistically significant differences between the two groups (see Appendix Table 1).

${ }^{13}$ Attriters were matched to control group non-attriters based on the following baseline characteristics: household size, number of dependents, owns home, acres of land owned, age, gender, currently a student, lives with at least one parent, completed primary school, married, previously received vocational training, previously started a business, and hours per year spent on agriculture, paid labor, and own business. 
statistically significant drop in personal savings for men as well as women, and the values remain larger for women. Women assigned to treatment also are less likely to migrate, a change that could result from assuming that attriters did not migrate, when in fact it is likely that a main cause of attrition is migration. In terms of social outcomes, women trainees are now significantly more likely to report that they are happy and satisfied with life, and that they are able to earn money outside of farming (this variable loses significance for men).

\section{Conclusions}

This study makes three important contributions. First, we are among the first to provide experimental evidence on the effects of vocational and entrepreneurship training in a country where the majority lack access to formal education and skills development. Apprenticeship training is particularly relevant in the Sub Saharan Africa setting, as programs that foster entrepreneurship provide alternatives to highly rationed wage employment. Second, we shed light on gender differentials in the effects of such programs, by documenting the additional constraints under which women have to make human capital investment decisions, and the resulting differences in the nature of their experiences during the training program. Third, by tracking a large fraction of program drop-outs at follow-up, we are able to both examine the determinants and consequences of drop-outs, and partially address a challenge faced by most published evaluations of training programs: many potential participants drop out, and the lack of follow-up data on drop-outs introduces selection biases.

We find that the vocational training program led to enhanced (selfreported) skills of the type that the training was intended to impart. Male trainees reacted by continuing to invest in their human capital development during the post-training period, but there were no significant effects on labor market outcomes in the short run. Participating in training was expensive, particularly for 
girls who had to draw down their savings and did not receive as much help from the trainers as the boys did. External constraints (such as illness and getting fired) more strongly affected girls' participation decisions. Girls could not attend as regularly as boys and were less likely to end up with job offers from their trainers. Overall, the experience led to more positive effects on self-reported well-being among male participants.

Given the continued investments in skills development that we observe among trainees, it would be valuable to follow this sample up over a longer period to identify whether the additional human capital leads to improved labor market outcomes in the long run. In this context, an important shortcoming of our analysis is that the follow-up survey was conducted only 4 months after the completion of the training program (on average). However, conducting the follow-up quickly allowed us to track down many of the drop-outs, which was valuable. 
Bibliography

Aggarwal, Ashwani, Christine Hofmann, and Alexander Phiri. 2010. "A Study on Informal Apprenticeship in Malawi." Employment Sector Employment Report 9.

Ashraf, Nava, Erica Field, and Jean Lee. 2010. "Household Bargaining and Excess Fertility: An Experimental Study in Zambia." BREAD Working Paper 282.

Ashraf, Nava, Xavier Giné, and Dean Karlan. 2009. "Finding Missing Markets (and a Disturbing Epilogue): Evidence from an Export Crop Adoption and Marketing Intervention in Kenya." American Journal of Agricultural Economics 91 (4): 973-990. doi:10.1111/j.1467-8276.2009.01319.x.

Attanasio, Orazio, Adriana Kugler, and Costas Meghir. 2011. "Subsidizing Vocational Training for Disadvantaged Youth in Colombia: Evidence from a Randomzied Trial." American Economic Journal: Applied Economics 3 (July 2011): 188-220.

Baird, Sarah, Ephraim Chirwa, Craig McIntosh, and Berk Özler. 2010. "The Short-Term Impacts of a Schooling Conditional Cash Transfer Program on the Sexual Behavior of Young Women." Health Economics 19 (S1): 55-68. doi:10.1002/hec.1569.

Baird, Sarah, Craig McIntosh, and Berk Özler. 2011. "Cash Or Condition? Evidence from a Cash Transfer Experiment." Quarterly Journal of Economics 126 (4): 1709-1753. doi:10.1093/qje/qjr032.

Banerjee, Abhijit, and Esther Duflo. 2007. "The Economic Lives of the Poor." Journal of Economic Perspectives 21 (1): 141-168.

Bartel, Ann P. 1995. "Training, Wage Growth, and Job Performance: Evidence from a Company Database." Journal of Labor Economics 13 (3): 401-425. http://www.jstor.org/stable/2535150.

Bergemann, Annette, and Gerard J. van den Berg. 2008. "Active Labor Market Policy Effects for Women in Europe - A Survey." Annals of Economics and Statistics / Annales d'Économie Et De Statistique (91/92, Econometric Evaluation of Public Policies: Methods and Applications): 385-408. http://www.jstor.org/stable/27917252.

Biavaschi, Costanza, Werner Eichhorst, Corrado Guilietti, Michael J. Kendzia, Janneke Pieters, Nuria Rodriguez-Planas, Ricarda Schmidl, and Klaus F. Zimmerman. 2012. "Youth Unemployment and Vocational Training." IZA Discussion Paper 6890. http://ftp.iza.org/dp6890.pdf. 
Biewen, Martin, Bernd Fitzenberger, Aderonke Osikominu, and Marie Waller. 2007. "Which Program for Whom? Evidence on the Comparative Effectiveness of Public Sponsored Training Programs in Germany." IZA Discussion Paper 2885. http://ftp.iza.org/dp2885.pdf.

Blattman, Christopher, Nathan Fiala, and Sebastian Martinez. 2012. "Employment Generation in Rural Africa: Mid-Term Results from an Experimental Evaluation of the Youth Opportunities Program in Northern Uganda." DIW Berlin Discussion Paper 1201. doi:http://dx.doi.org/10.2139/ssrn.2030866.

Bring, Johan, and Kenneth Carling. 2000. "Attrition and Misclassification of Drop-Outs in the Analysis of Unemployment Duration." Journal of Official Statistics 16 (4): 321-330.

Bruhn, Miriam and Bilal Zia. 2011. "Stimulating Managerial Capital in Emerging Markets: The Impact of Business and Financial Literacy for Young Entrepreneurs." Policy Research Working Paper 5642. http://go.worldbank.org/QPTPGZ8KD0.

Calderon, Gabriela, Jessica Cunha, and Giacomo De Giorgi. 2013. "Business Literacy and Development: Evidence from a Randomized Controlled Trial in Rural Mexico.". http://www.stanford.edu/ gabcal/financial_literacy.pdf.

Card, David, Pablo Ibarraran, Ferdinando Regalia, David Rosas Shady, and Yuri Soares. 2011. "The Labor Market Impacts of Youth Training in the Dominican Republic." Journal of Labor Economics 29 (2): 267-300. doi:10.1086/658090.

Card, David, Jochen Kluve, and Andrea Weber. 2010. "Active Labour Market Policy Evaluations: A Meta-Analysis." Economic Journal 120 (548): F452F477. doi:10.1111/j.1468-0297.2010.02387.x.

Cho, Yoonyoung and Maddalena Honorati. 2013. "Entrepreneurship Programs in Developing Countries: A Meta Regression Analysis." IZA Discussion Paper 7333. http://ssrn.com/abstract=2250332.

Chong, Alberto and Jose Galdo. 2006. "Does the Quality of Training Programs Matter? Evidence from Bidding Processes Data." IZA Discussion Paper 2202. http://ssrn.com/abstract=920642.

Cole, Shawn, Thomas Sampson, and Bilal Zia. 2011. "Prices Or Knowledge? what Drives Demand for Financial Services in Emerging Markets?" The Journal of Finance 66 (6): 1933-1967. doi:10.1111/j.15406261.2011.01696.x.

de Mel, Suresh, David McKenzie, and Christopher Woodruff. 2011. "Business Training and Female Enterprise Start-Up, Growth, and Dynamics: 
Experimental Evidence from Sri Lanka." Policy Research Working Paper 6145. http://go.worldbank.org/4WOEGCDHD0.

Devoto, Florencia, Esther Duflo, Pascaline Dupas, William Pariente, and Vincent Pons. 2012. "Happiness on Tap: Piped Water Adoption in Urban Morocco." American Economic Journal: Economic Policy 4 (4): 68-99.

DiNardo, John, Justin McCrary, and Lisa Sanbonmatsu. 2006. "Constructive Proposals for Dealing with Attrition: An Empirical Example.". http://wwwpersonal.umich.edu/ jdinardo/DMS_v9.pdf.

Drexler, Alejandro, Greg Fischer, and Antoinette Schoar. 2011. "Keeping it Simple: Financial Literacy and Rules of Thumb.". http://www.mit.edu/ aschoar/KIS\%20DFS\%20Jan2011.pdf.

Duflo, Esther, Michael Greenstone, and Rema Hanna. 2012. "Up in Smoke: The Influence of Household Behavior on the Long-Run Impact of Improved Cooking Stoves." MIT Department of Economics Working Paper 12-10. http://papers.ssrn.com/sol3/papers.cfm?abstract_id=2039004.

Frazis, Harley, and Mark A. Loewenstein. 2005. "Reexamining the Returns to Training: Functional Form, Magnitude, and Interpretation." The Journal of Human Resources 40 (2): 453-476. http://www.jstor.org/stable/4129533.

Friedlander, Daniel, David Greenberg, and Philip Robins. 1997. "Evaluating Government Training Programs for the Economically Disadvantaged." Journal of Economic Literature 35 (4): 1809-1855.

Gerfin, M., and M. Lechner. 2002. "A Microeconometric Evaluation of the Active Labour Market Policy in Switzerland." Economic Journal 112 (482): 854893. doi:10.1111/1468-0297.00072.

Heckman, James J., Neil Hohmann, Jeffrey Smith, and Michael Khoo. 2000. "Substitution and Dropout Bias in Social Experiments: A Study of an Influential Social Experiment." The Quarterly Journal of Economics 115 (2): 651-694. doi:10.1162/003355300554764.

Heckman, James J., Hidehiko Ichimura, Jeffrey Smith, and Petra Todd. 1998. "Characterizing Selection Bias using Experimental Data." Econometrica 66 (5): 1017-1098. doi:10.2307/2999630.

Heckman, James J., Robert J. Lalonde, and Jeffrey Smith. 1999. "The Economics and Econometrics of Active Labor Market Programs." In Handbook of Labor Economics [null], edited by Orley Ashenfelter and David Card. Vol. 3, 18652097. New York: Elsevier. 
Heckman, James J., Lance Lochner, and Christopher Taber. 1998. "Explaining Rising Wage Inequality: Explorations with a Dynamic General Equilibrium Model of Labor Earnings with Heterogeneous Agents." Review of Economic Dynamics 1 (1): 1-58. doi:10.1006/redy.1997.0008.

Horowitz, Joel L., and Charles F. Manski. 1998. "Censoring of Outcomes and Regressors due to Survey Nonresponse: Identification and Estimation using Weights and Imputations." Journal of Econometrics 84 (1): 37-58. doi:10.1016/S0304-4076(97)00077-8.

_. 2000. "Nonparametric Analysis of Randomized Experiments with Missing Covariate and Outcome Data." Journal of the American Statistical Association 95 (449): 77-84. http://www.jstor.org/stable/2669526.

ILO. 2012. "Upgrading Informal Apprenticeship: A Resource Guide for Africa." .

International Labour Organization. "Key Indicators of the Labour Market.", accessed April 10, 2013, http://www.ilo.org/empelm/what/WCMS_114240/lang--en/index.htm.

Jespersen, Svend, Jakob Munch, and Lars Skipper. 2008. "Costs and Benefits of Danish Active Labour Market Programmes." Labour Economics 15 (5): 859884. doi:10.1016/j.labeco.2007.07.005.

Karlan, Dean, and Martin Valdivia. 2011. "Teaching Entrepreneurship: Impact of Business Training on Microfinance Clients and Institutions." The Review of Economics and Statistics 93 (2): 510-527.

Kluve, Jochen. 2010. "The Effectiveness of European Active Labor Market Programs." Labour Economics 17 (6): 904-918. doi:10.1016/j.labeco.2010.02.004.

Lee, David S. 2009. "Training, Wages, and Sample Selection: Estimating Sharp Bounds on Treatment Effects." The Review of Economic Studies 76 (3): 1071-1102. http://www.jstor.org/stable/40247633.

Lynch, Lisa M. 1992. "Private-Sector Training and the Earnings of Young Workers." The American Economic Review 82 (1): 299-312. http://www.jstor.org/stable/2117617.

Manski, Charles F. 1989. "Anatomy of the Selection Problem." The Journal of Human Resources 24 (3): 343-360. http://www.jstor.org/stable/145818. 1990. "Nonparametric Bounds on Treatment Effects." The American Economic Review 80 (2, Papers and Proceedings of the Hundred and Second Annual Meeting of the American Economic Association): 319-323. http://www.jstor.org/stable/2006592. 
Meredith, Jennifer, Jonathan Robinson, Sarah Walker, and Bruce Wydick. 2011. "Keeping the Doctor Away: Experimental Evidence on Investment in Preventative Health Products.". http://people.ucsc.edu/ jmrtwo/HealthProducts.pdf.

Miguel, Edward, and Michael Kremer. 2004. "Worms: Identifying Impacts on Education and Health in the Presence of Treatment Externalities." Econometrica 72 (1): 159-217.

Miller, Grant and A. M. Mobarak. 2012. "Learning about New Technologies through Opinion Leaders and Social Networks: Experimental Evidence on Non-Traditional Cookstoves in Rural Bangladesh.". http://faculty.som.yale.edu/mushfiqmobarak/stove_MS.pdf.

Mobarak, Ahmed Mushfiq and Mark R. Rosenzweig. 2012. "Selling Formal Insurance to the Informally Insured." Yale University Economic Growth Center Discussion Paper 1007. doi:http://dx.doi.org/10.2139/ssrn.2009528.

Monk, Courtney, Justin Sandefur, and Francis Teal. 2008. "Does Doing an Apprenticeship Pay Off? Evidence from Ghana." Centre for the Study of African Economies Working Paper Series 2008-08. http://www.csae.ox.ac.uk/workingpapers/pdfs/2008-08text.pdf.

National Statistical Office. "Malawi - Third Integrated Household Survey 20102011.", accessed April 10, 2013, http://microdata.worldbank.org/index.php/catalog/1003.

Newhouse, David, and Daniel Suryadarma. 2011. "The Value of Vocational Education: High School Type and Labor Market Outcomes in Indonesia." The World Bank Economic Review 25 (2): 296-322. doi:10.1093/wber/lhr010.

Owolabi, Oluwarotimi and Sarmistha Pal. 2011. "The Value of Business Networks in Emerging Economies: An Analysis of Firms' External Financing Opportunities. " IZA Discussion Paper 5738. http://ssrn.com/abstract=1855190.

Sianesi, Barbara. 2004. "An Evaluation of the Swedish System of Active Labor Market Programs in the 1990s." The Review of Economics and Statistics 86 (1): 133-155. doi:10.1162/003465304323023723.

The World Bank. "World Development Indicators.", accessed April 1, 2013, http://data.worldbank.org/data-catalog/world-development-indicators.

_ . . 2012b. "World Development Report 2013: Jobs." . http://go.worldbank.org/TM7GTEB8U0. 
Figure 1: Study Design

1900

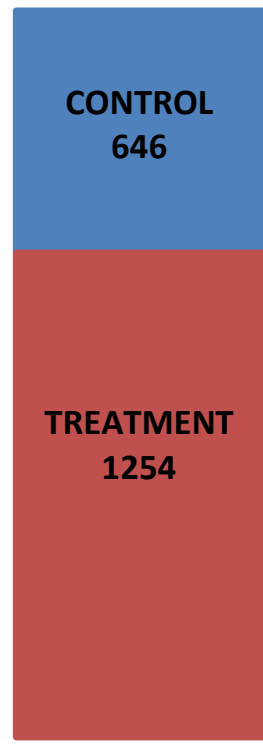

\section{BASELINE}

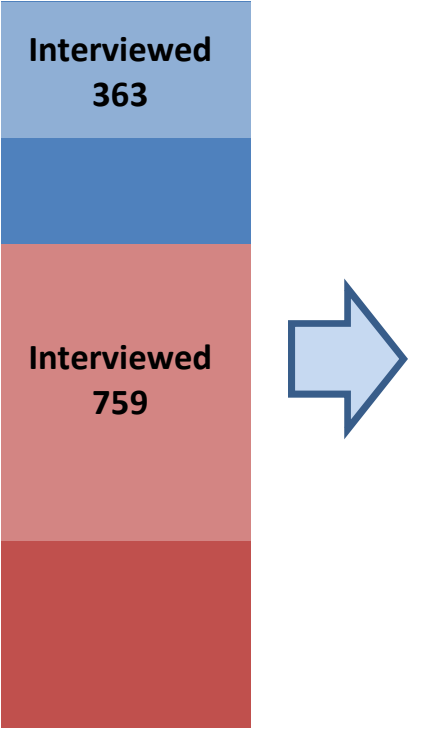

Drop-outs

307 Totat 106

including administrativ

dropoútst
TRAINING

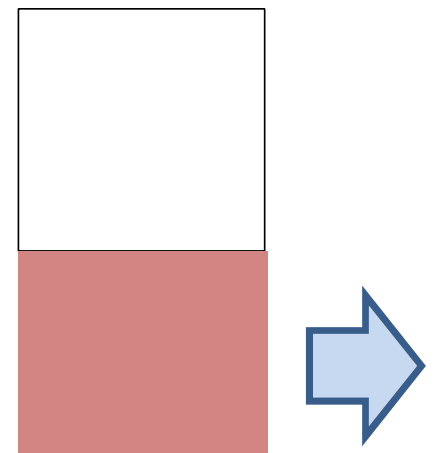

Baseline and

Follow-up

$N=517$

Follow-up Only $\quad \mathrm{N}=181$

Never Surveyed N=314

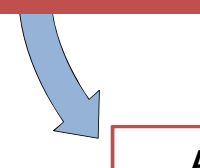

Attrition

(=Baseline

Only: 367) 


\begin{tabular}{|c|c|c|c|}
\hline & Control & Treatment & $\begin{array}{l}\text { P-value of } \\
\text { difference }\end{array}$ \\
\hline $\mathrm{N}$ & 363 & 759 & \\
\hline \multicolumn{4}{|l|}{ Household Characteristics } \\
\hline Household size & 5.35 & 5.48 & 0.41 \\
\hline Number of adults & 2.74 & 2.67 & 0.46 \\
\hline Number of children $<18$ & 2.21 & 2.39 & 0.12 \\
\hline $\begin{array}{l}\text { Number of respondent's dependents (in or } \\
\text { out of hh) }\end{array}$ & 0.88 & 0.81 & 0.40 \\
\hline Owns home=1 & 0.89 & 0.87 & 0.52 \\
\hline Number of acres of land owned & 1.91 & 1.84 & 0.65 \\
\hline Value of assets (in MWK) & $29,465.43$ & $31,260.54$ & 0.68 \\
\hline \multicolumn{4}{|l|}{ Construction of walls } \\
\hline Unburnt bricks & 0.37 & 0.40 & 0.29 \\
\hline Burnt bricks & 0.49 & 0.46 & 0.30 \\
\hline \multicolumn{4}{|l|}{ Construction of roof } \\
\hline Grass & 0.62 & 0.62 & 0.98 \\
\hline Iron sheets & 0.37 & 0.36 & 0.69 \\
\hline \multicolumn{4}{|l|}{ Source of water } \\
\hline Unprotected well & 0.12 & 0.09 & 0.11 \\
\hline Communal tap & 0.19 & 0.18 & 0.94 \\
\hline Borehole & 0.51 & 0.53 & 0.48 \\
\hline \multicolumn{4}{|l|}{ Individual Characteristics } \\
\hline Gender:Male=1 & 0.69 & 0.66 & 0.39 \\
\hline Age & 21.55 & 21.44 & 0.58 \\
\hline Head of household=1 & 0.17 & 0.18 & 0.57 \\
\hline Married or living with partner=1 & 0.18 & 0.16 & 0.22 \\
\hline Neither parents are alive (orphan) $=1$ & 0.38 & 0.35 & 0.40 \\
\hline \multicolumn{4}{|l|}{ Educational Attainment } \\
\hline Completed primary & 0.05 & 0.05 & 0.83 \\
\hline Some secondary & 0.48 & 0.48 & 0.94 \\
\hline Completed Secondary & 0.26 & 0.22 & 0.13 \\
\hline Currently a student $=1$ & 0.11 & 0.10 & 0.61 \\
\hline Previously received vocational training $=1$ & 0.13 & 0.13 & 0.69 \\
\hline Previously started a business $=1$ & 0.39 & 0.32 & 0.04 \\
\hline \multicolumn{4}{|l|}{ Economic Variables } \\
\hline Annual personal income & $19,431.62$ & $26,155.18$ & 0.48 \\
\hline Number of loans in past 12 months & 0.38 & 0.37 & 0.73 \\
\hline $\begin{array}{l}\text { Amount of loans in past } 12 \text { months (in } \\
\text { MWK) }\end{array}$ & $2,636.84$ & $2,486.41$ & 0.74 \\
\hline $\begin{array}{l}\text { Number of cash and in-kind grants from } \\
\text { social programs in past } 6 \text { months }\end{array}$ & 0.68 & 0.68 & 0.93 \\
\hline $\begin{array}{l}\text { Amount of cash grants from social } \\
\text { programs in past } 6 \text { months (in MWK) }\end{array}$ & $5,613.88$ & $6,870.36$ & 0.60 \\
\hline \multicolumn{4}{|l|}{$\begin{array}{l}\text { How often do you/other adults skip } \\
\text { meals? }\end{array}$} \\
\hline Often & 0.27 & 0.30 & 0.33 \\
\hline Sometimes & 0.54 & 0.55 & 0.81 \\
\hline Not at all & 0.19 & 0.15 & 0.13 \\
\hline
\end{tabular}


Table 2: Occupations in which participants received training

\begin{tabular}{lcccc}
\hline & Total Trained & \% Men & \% Women & Average Months of Training \\
\hline Auto & 119 & $81 \%$ & $19 \%$ & 3.19 \\
Beauty & 44 & $19 \%$ & $81 \%$ & 2.91 \\
Clothing & 167 & $38 \%$ & $62 \%$ & 2.99 \\
Construction & 158 & $94 \%$ & $6 \%$ & 3.00 \\
Electronics & 56 & $69 \%$ & $31 \%$ & 3.00 \\
Food & 20 & $36 \%$ & $64 \%$ & 3.09 \\
Metalwork & 73 & $83 \%$ & $17 \%$ & 2.99 \\
Other & 36 & $67 \%$ & $33 \%$ & 3.33 \\
\hline \hline
\end{tabular}


Table 3a: Summary Statistics at Baseline - Difference between dropout and attrition

\begin{tabular}{|c|c|c|c|c|c|c|}
\hline & $\begin{array}{c}\text { Dropped out (inc. } \\
\text { administrative } \\
\text { dropouts) } \\
\end{array}$ & Attrited & $\begin{array}{l}\text { P-value of } \\
\text { difference }\end{array}$ & $\begin{array}{l}\text { Dropped out (not inc. } \\
\text { administrative } \\
\text { dropouts) } \\
\end{array}$ & Attrited & $\begin{array}{l}\text { P-value of } \\
\text { difference }\end{array}$ \\
\hline $\mathrm{N}$ & 230 & 367 & & 70 & 367 & \\
\hline \multicolumn{7}{|l|}{ Household Characteristics } \\
\hline Household size & 5.70 & 5.15 & 0.01 & 5.53 & 5.15 & 0.21 \\
\hline Number of adults & 2.83 & 2.58 & 0.04 & 2.70 & 2.58 & 0.48 \\
\hline Number of children $<18$ & 2.43 & 2.14 & 0.05 & 2.47 & 2.14 & 0.15 \\
\hline $\begin{array}{l}\text { Number of respondent's dependents (in } \\
\text { or out of hh) }\end{array}$ & 0.62 & 1.06 & 0.00 & 0.64 & 1.06 & 0.03 \\
\hline Owns home $=1$ & 0.88 & 0.85 & 0.25 & 0.87 & 0.85 & 0.63 \\
\hline Number of acres of land owned & 1.90 & 1.87 & 0.90 & 2.17 & 1.87 & 0.43 \\
\hline Value of assets (in MWK) & $35,298.70$ & $22,808.99$ & 0.00 & $24,975.00$ & $22,808.99$ & 0.66 \\
\hline \multicolumn{7}{|l|}{ Construction of walls } \\
\hline Unburnt bricks & 0.38 & 0.40 & 0.59 & 0.34 & 0.40 & 0.37 \\
\hline Burnt bricks & 0.48 & 0.49 & 0.85 & 0.53 & 0.49 & 0.56 \\
\hline \multicolumn{7}{|l|}{ Construction of roof } \\
\hline Grass & 0.63 & 0.57 & 0.16 & 0.54 & 0.57 & 0.65 \\
\hline Iron sheets & 0.35 & 0.41 & 0.15 & 0.41 & 0.41 & 0.96 \\
\hline \multicolumn{7}{|l|}{ Source of water } \\
\hline Unprotected well & 0.08 & 0.10 & 0.30 & 0.06 & 0.10 & 0.23 \\
\hline Communal tap & 0.16 & 0.21 & 0.12 & 0.19 & 0.21 & 0.61 \\
\hline Borehole & 0.54 & 0.50 & 0.35 & 0.63 & 0.50 & 0.05 \\
\hline \multicolumn{7}{|l|}{ Individual Characteristics } \\
\hline Gender:Male=1 & 0.66 & 0.66 & 1.00 & 0.63 & 0.66 & 0.65 \\
\hline Age & 20.36 & 23.26 & 0.00 & 20.29 & 23.26 & 0.00 \\
\hline Head of household=1 & 0.15 & 0.24 & 0.01 & 0.20 & 0.24 & 0.47 \\
\hline Married or living with partner=1 & 0.17 & 0.20 & 0.24 & 0.13 & 0.20 & 0.14 \\
\hline Neither parents are alive (orphan) $=1$ & 0.35 & 0.35 & 0.88 & 0.35 & 0.35 & 0.94 \\
\hline \multicolumn{7}{|l|}{ Educational Attainment } \\
\hline Completed primary & 0.04 & 0.05 & 0.75 & 0.01 & 0.05 & 0.19 \\
\hline Some secondary & 0.46 & 0.52 & 0.16 & 0.46 & 0.52 & 0.33 \\
\hline Completed Secondary & 0.23 & 0.24 & 0.76 & 0.16 & 0.24 & 0.14 \\
\hline Currently a student=1 & 0.16 & 0.05 & 0.00 & 0.14 & 0.05 & 0.00 \\
\hline Previously received vocational training $=1$ & 0.15 & 0.12 & 0.38 & 0.11 & 0.12 & 0.85 \\
\hline Previously started a business $=1$ & 0.30 & 0.39 & 0.03 & 0.27 & 0.39 & 0.06 \\
\hline \multicolumn{7}{|l|}{ Economic Variables } \\
\hline Annual personal income & $15,974.95$ & $30,202.99$ & 0.09 & $8,795.68$ & $30,202.99$ & 0.14 \\
\hline Number of loans in past 12 months & 0.37 & 0.38 & 0.87 & 0.36 & 0.38 & 0.78 \\
\hline $\begin{array}{l}\text { Amount of loans in past } 12 \text { months (in } \\
\text { MWK) }\end{array}$ & $2,223.99$ & 2,834.19 & 0.26 & $2,413.91$ & 2,834.19 & 0.65 \\
\hline $\begin{array}{l}\text { Number of cash and in-kind grants from } \\
\text { social programs in past } 6 \text { months }\end{array}$ & 0.66 & 0.73 & 0.28 & 0.61 & 0.73 & 0.27 \\
\hline $\begin{array}{l}\text { Amount of cash grants from social } \\
\text { programs in past } 6 \text { months (in MWK) }\end{array}$ & $16,019.21$ & $5,133.32$ & 0.02 & $13,016.67$ & $5,133.32$ & 0.11 \\
\hline \multicolumn{7}{|l|}{$\begin{array}{l}\text { How often do you/other adults skip } \\
\text { meals? }\end{array}$} \\
\hline Often & 0.31 & 0.29 & 0.48 & 0.37 & 0.29 & 0.15 \\
\hline Sometimes & 0.55 & 0.54 & 0.81 & 0.53 & 0.54 & 0.83 \\
\hline Not at all & 0.13 & 0.17 & 0.23 & 0.10 & 0.17 & 0.13 \\
\hline
\end{tabular}


Table 3b: Effect of treatment assignment on likelihood of attrition (surveyed at baseline but not at follow-up)

\begin{tabular}{|c|c|c|c|c|c|c|c|c|c|}
\hline & \multicolumn{3}{|c|}{ All } & \multicolumn{3}{|c|}{ Men } & \multicolumn{3}{|c|}{ Women } \\
\hline & $(1)$ & $(2)$ & $(3)$ & (4) & (5) & (6) & $(7)$ & $(8)$ & (9) \\
\hline Treatment Assignment & $\begin{array}{c}-0.026 \\
{[0.030]}\end{array}$ & $\begin{array}{c}-0.017 \\
{[0.025]}\end{array}$ & $\begin{array}{c}-0.009 \\
{[0.024]}\end{array}$ & $\begin{array}{c}0.000 \\
{[0.036]}\end{array}$ & $\begin{array}{c}0.015 \\
{[0.031]}\end{array}$ & $\begin{array}{c}0.010 \\
{[0.029]}\end{array}$ & $\begin{array}{c}-0.082 \\
{[0.055]}\end{array}$ & $\begin{array}{c}-0.089 * \\
{[0.049]}\end{array}$ & $\begin{array}{c}-0.062 \\
{[0.045]}\end{array}$ \\
\hline Household size & & & $\begin{array}{l}-0.009 * \\
{[0.005]}\end{array}$ & & & $\begin{array}{l}-0.004 \\
{[0.007]}\end{array}$ & & & $\begin{array}{c}-0.019 * * \\
{[0.009]}\end{array}$ \\
\hline $\begin{array}{l}\text { Number of dependents (in or out of } \\
\text { hh) }\end{array}$ & & & $\begin{array}{c}0.009 \\
{[0.009]}\end{array}$ & & & $\begin{array}{c}0.013 \\
{[0.011]}\end{array}$ & & & $\begin{array}{c}0.001 \\
{[0.015]}\end{array}$ \\
\hline Owns home $=1$ & & & $\begin{array}{c}-0.083^{* *} \\
{[0.039]}\end{array}$ & & & $\begin{array}{c}-0.120 * * \\
{[0.051]}\end{array}$ & & & $\begin{array}{c}-0.016 \\
{[0.068]}\end{array}$ \\
\hline Value of assets (in MK) & & & $\begin{array}{c}-0.000 * * \\
{[0.000]}\end{array}$ & & & $\begin{array}{c}-0.000 * * * \\
{[0.000]}\end{array}$ & & & $\begin{array}{c}0.000 \\
{[0.000]}\end{array}$ \\
\hline Age & & & $\begin{array}{c}0.052 * * * \\
{[0.004]}\end{array}$ & & & $\begin{array}{c}0.054^{* * *} \\
{[0.005]}\end{array}$ & & & $\begin{array}{c}0.051^{* * *} \\
{[0.007]}\end{array}$ \\
\hline Head of household=1 & & & $\begin{array}{c}0.005 \\
{[0.036]}\end{array}$ & & & $\begin{array}{c}0.027 \\
{[0.046]}\end{array}$ & & & $\begin{array}{l}-0.029 \\
{[0.077]}\end{array}$ \\
\hline Married or living with partner $=1$ & & & $\begin{array}{l}-0.061 * \\
{[0.035]}\end{array}$ & & & $\begin{array}{l}-0.072 * \\
{[0.044]}\end{array}$ & & & $\begin{array}{c}-0.074 \\
{[0.069]}\end{array}$ \\
\hline Currently a student=1 & & & $\begin{array}{c}0.035 \\
{[0.037]}\end{array}$ & & & $\begin{array}{c}0.027 \\
{[0.045]}\end{array}$ & & & $\begin{array}{c}0.053 \\
{[0.070]}\end{array}$ \\
\hline Previously started a business $=1$ & & & $\begin{array}{c}0.004 \\
{[0.025]}\end{array}$ & & & $\begin{array}{c}0.006 \\
{[0.030]}\end{array}$ & & & $\begin{array}{c}0.004 \\
{[0.049]}\end{array}$ \\
\hline District Dummies? & No & Yes & Yes & No & Yes & Yes & No & Yes & Yes \\
\hline Constant & $\begin{array}{c}0.344^{* * *} \\
{[0.025]}\end{array}$ & $\begin{array}{c}0.261^{* *} \\
{[0.106]}\end{array}$ & $\begin{array}{c}-0.687 * * * \\
{[0.129]}\end{array}$ & $\begin{array}{c}0.320 * * * \\
{[0.030]}\end{array}$ & $\begin{array}{c}0.072 \\
{[0.060]}\end{array}$ & $\begin{array}{c}-0.928 * * * \\
{[0.147]}\end{array}$ & $\begin{array}{c}0.398 * * * \\
{[0.046]}\end{array}$ & $\begin{array}{c}0.189 \\
{[0.223]}\end{array}$ & $\begin{array}{c}-0.768 * * \\
{[0.313]}\end{array}$ \\
\hline Observations & 1,122 & 1,122 & 1,117 & 753 & 753 & 748 & 369 & 369 & 369 \\
\hline R-squared & 0.001 & 0.291 & 0.419 & 0.000 & 0.287 & 0.425 & 0.006 & 0.320 & 0.437 \\
\hline F-test & & & 23.70 & & & 18.17 & & & 6.565 \\
\hline F-test pvalue & & & 0 & & & 0 & & & $1.25 \mathrm{e}-08$ \\
\hline
\end{tabular}

Robust standard errors in brackets

*** $\mathrm{p}<0.01,{ }^{* *} \mathrm{p}<0.05, * \mathrm{p}<0.1$

The F-test is a test of joint significance of all the control variables. 
Table 4: Dropouts by Training Industry

\begin{tabular}{lccc}
\hline & $\begin{array}{c}\text { \% Dropped out (inc. } \\
\text { admin. dropouts) }\end{array}$ & $\begin{array}{c}\text { \% Dropped out of those } \\
\text { who were invited }\end{array}$ & $\begin{array}{c}\text { \% Not invited (of those } \\
\text { who dropped out) }\end{array}$ \\
\hline Auto & $60.2 \%$ & $30.9 \%$ & $82.1 \%$ \\
Beauty & $38.6 \%$ & $18.2 \%$ & $75.0 \%$ \\
Clothing & $38.9 \%$ & $24.4 \%$ & $69.8 \%$ \\
Construction & $39.9 \%$ & $15.9 \%$ & $81.7 \%$ \\
Electronics & $56.9 \%$ & $19.4 \%$ & $88.1 \%$ \\
Food & $45.0 \%$ & $26.7 \%$ & $69.2 \%$ \\
Metalwork & $30.3 \%$ & $19.7 \%$ & $61.0 \%$ \\
Other & $67.6 \%$ & $29.4 \%$ & $91.4 \%$ \\
Total & $45.1 \%$ & $22.2 \%$ & $78.4 \%$ \\
\hline \hline
\end{tabular}


Table 5: Effects of shocks on likelihood of dropping out (OLS)

\begin{tabular}{|c|c|c|c|c|}
\hline & \multicolumn{2}{|c|}{$\begin{array}{l}\text { Dropped out (inc. } \\
\text { administrative }\end{array}$} & \multicolumn{2}{|c|}{$\begin{array}{l}\text { Dropped out (not inc. } \\
\text { administrative }\end{array}$} \\
\hline & Men & Women & Men & Women \\
\hline Fired in past 12 months & $\begin{array}{c}0.019 \\
{[0.106]}\end{array}$ & $\begin{array}{l}-0.243^{*} \\
{[0.136]}\end{array}$ & $\begin{array}{c}0.127 \\
{[0.127]}\end{array}$ & $\begin{array}{c}-0.290 * * * \\
{[0.088]}\end{array}$ \\
\hline $\begin{array}{l}\text { Incapacitated in past } 12 \text { months (severe } \\
\text { illness or injury) }\end{array}$ & $\begin{array}{l}-0.109 \\
{[0.074]}\end{array}$ & $\begin{array}{c}0.104 \\
{[0.075]}\end{array}$ & $\begin{array}{l}-0.095 \\
{[0.078]}\end{array}$ & $\begin{array}{c}0.163 \\
{[0.113]}\end{array}$ \\
\hline $\begin{array}{l}\text { Someone in hh was incapacitated in past } \\
12 \text { months }\end{array}$ & $\begin{array}{c}-0.011 \\
{[0.038]}\end{array}$ & $\begin{array}{c}-0.034 \\
{[0.054]}\end{array}$ & $\begin{array}{c}0.023 \\
{[0.046]}\end{array}$ & $\begin{array}{l}-0.057 \\
{[0.068]}\end{array}$ \\
\hline $\begin{array}{l}\text { Household member died in past } 12 \\
\text { months }\end{array}$ & $\begin{array}{c}0.009 \\
{[0.064]}\end{array}$ & $\begin{array}{c}-0.016 \\
{[0.067]}\end{array}$ & $\begin{array}{c}0.016 \\
{[0.082]}\end{array}$ & $\begin{array}{c}-0.024 \\
{[0.100]}\end{array}$ \\
\hline Had child in past year & $\begin{array}{c}0.023 \\
{[0.085]}\end{array}$ & $\begin{array}{c}0.063 \\
{[0.095]}\end{array}$ & $\begin{array}{c}0.109 \\
{[0.100]}\end{array}$ & $\begin{array}{c}0.095 \\
{[0.122]}\end{array}$ \\
\hline Married within the last year & $\begin{array}{c}0.020 \\
{[0.061]}\end{array}$ & $\begin{array}{c}0.074 \\
{[0.071]}\end{array}$ & $\begin{array}{l}-0.029 \\
{[0.071]}\end{array}$ & $\begin{array}{c}0.049 \\
{[0.107]}\end{array}$ \\
\hline $\begin{array}{l}\text { Migrated permanently or temporarily, } \\
\text { for work, school or other }\end{array}$ & $\begin{array}{c}0.057 \\
{[0.042]}\end{array}$ & $\begin{array}{c}0.040 \\
{[0.054]}\end{array}$ & $\begin{array}{l}0.119 * * \\
{[0.053]}\end{array}$ & $\begin{array}{c}0.032 \\
{[0.073]}\end{array}$ \\
\hline $\begin{array}{l}\text { Lives more than } 4 \mathrm{~km} \text { from training } \\
\text { center }\end{array}$ & $\begin{array}{l}-0.082 \\
{[0.070]}\end{array}$ & $\begin{array}{c}0.077 \\
{[0.103]}\end{array}$ & $\begin{array}{l}-0.006 \\
{[0.077]}\end{array}$ & $\begin{array}{c}0.096 \\
{[0.124]}\end{array}$ \\
\hline $\begin{array}{l}\text { Has close friends or relatives at training } \\
\text { site }\end{array}$ & $\begin{array}{c}-0.676 * * * \\
{[0.036]}\end{array}$ & $\begin{array}{c}-0.614^{* * *} \\
{[0.053]}\end{array}$ & $\begin{array}{c}-0.325^{* * *} \\
{[0.067]}\end{array}$ & $\begin{array}{c}-0.326 * * * \\
{[0.084]}\end{array}$ \\
\hline $\begin{array}{l}\text { Hours worked in paid labor in month } \\
\text { before training }\end{array}$ & $\begin{array}{l}-0.000 \\
{[0.000]}\end{array}$ & $\begin{array}{c}0.000 \\
{[0.000]}\end{array}$ & $\begin{array}{c}-0.000 \\
{[0.000]}\end{array}$ & $\begin{array}{c}0.000 \\
{[0.001]}\end{array}$ \\
\hline $\begin{array}{l}\text { Hours worked in self employment in } \\
\text { month before training }\end{array}$ & $\begin{array}{l}-0.000 \\
{[0.000]}\end{array}$ & $\begin{array}{c}0.000 \\
{[0.000]}\end{array}$ & $\begin{array}{l}-0.000 \\
{[0.000]}\end{array}$ & $\begin{array}{c}0.001 \\
{[0.001]}\end{array}$ \\
\hline $\begin{array}{l}\text { Hours spent in human capital } \\
\text { development (school, job or trade } \\
\text { training) in month before training }\end{array}$ & $\begin{array}{c}0.000 \\
{[0.000]}\end{array}$ & $\begin{array}{c}0.000 \\
{[0.001]}\end{array}$ & {$[0.001]$} & {$[0.001]$} \\
\hline _cons & $\begin{array}{c}0.832 * * * \\
{[0.041]}\end{array}$ & $\begin{array}{c}0.739 * * * \\
{[0.066]}\end{array}$ & $\begin{array}{c}0.431 * * * \\
{[0.079]}\end{array}$ & $\begin{array}{c}0.445^{* * *} \\
{[0.096]}\end{array}$ \\
\hline Number of observations & 436 & 236 & 304 & 168 \\
\hline Adjusted R2 & 0.438 & 0.380 & 0.101 & 0.085 \\
\hline
\end{tabular}

note: ${ }^{* * *} \mathrm{p}<0.01,{ }^{* *} \mathrm{p}<0.05,{ }^{*} \mathrm{p}<0.1$. Robust standard errors in brackets. 
Table 6: Effects of training on skills development ${ }^{(1)}$

\begin{tabular}{|c|c|c|c|c|c|c|c|}
\hline & \multicolumn{3}{|c|}{ ITT - Invited to Training } & \multicolumn{3}{|c|}{ IV - Attended Training } & \multirow[b]{2}{*}{$\begin{array}{c}\text { Mean of Dependent } \\
\text { variable in Control } \\
\text { group }\end{array}$} \\
\hline & No controls & $\begin{array}{l}+ \text { District } \\
\text { Dummies }\end{array}$ & $\begin{array}{c}+ \text { Controls and } \\
\text { District } \\
\text { Dummies }^{(2)}\end{array}$ & No controls & $\begin{array}{l}+ \text { District } \\
\text { Controls }\end{array}$ & $\begin{array}{l}\text { +Controls and } \\
\text { District Dummies }\end{array}$ & \\
\hline $\begin{array}{l}\text { Skill in area/tradetoday (1:Poor/None } \\
\text { 10:master craftsmen) }\end{array}$ & $\begin{array}{c}2.636 * * * \\
{[0.181]}\end{array}$ & $\begin{array}{c}2.718 * * * \\
{[0.169]}\end{array}$ & $\begin{array}{c}1.108 * * * \\
{[0.198]}\end{array}$ & $\begin{array}{c}4.890 * * * \\
{[0.316]}\end{array}$ & $\begin{array}{c}5.086 * * * \\
{[0.284]}\end{array}$ & $\begin{array}{c}4.969 * * * \\
{[0.790]}\end{array}$ & 2.578 \\
\hline $\begin{array}{l}\text { Knows calculate profits of a business } \\
\text { (today, 1-10) }\end{array}$ & $\begin{array}{c}1.632 * * * \\
{[0.207]}\end{array}$ & $\begin{array}{c}1.659 * * * \\
{[0.200]}\end{array}$ & $\begin{array}{l}0.578 * * \\
{[0.233]}\end{array}$ & $\begin{array}{c}2.970 * * * \\
{[0.377]}\end{array}$ & $\begin{array}{c}3.046 * * * \\
{[0.355]}\end{array}$ & $\begin{array}{l}2.450 * * \\
{[0.996]}\end{array}$ & 4.272 \\
\hline Knows how to start a business(today) $=1$ & $\begin{array}{c}0.241^{* * * *} \\
{[0.033]}\end{array}$ & $\begin{array}{c}0.235^{* * *} \\
{[0.033]}\end{array}$ & $\begin{array}{l}0.093 * * \\
{[0.040]}\end{array}$ & $\begin{array}{c}0.446 * * * \\
{[0.061]}\end{array}$ & $\begin{array}{c}0.439 * * * \\
{[0.061]}\end{array}$ & $\begin{array}{l}0.422 * * \\
{[0.173]}\end{array}$ & 0.438 \\
\hline
\end{tabular}
note: ${ }^{* * *} \mathrm{p}<0.01,{ }^{* *} \mathrm{p}<0.05,{ }^{*} \mathrm{p}<0.1$. Robust standard errors in brackets. Sample size $=975$.

${ }^{(1)}$ Dependent variables in first column. Coefficient is on the dummy variableInvited Training for ITT estimates and on Attended Training for IV estimates.

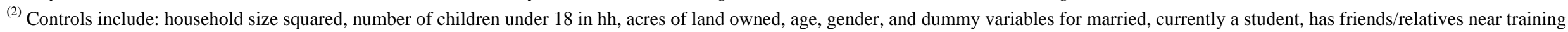
site, and whether a hh member who was contributing to hh income died in the past 12 months. 
Table 7: Effects on Time Use - Before, During and After Training ${ }^{(1)}$

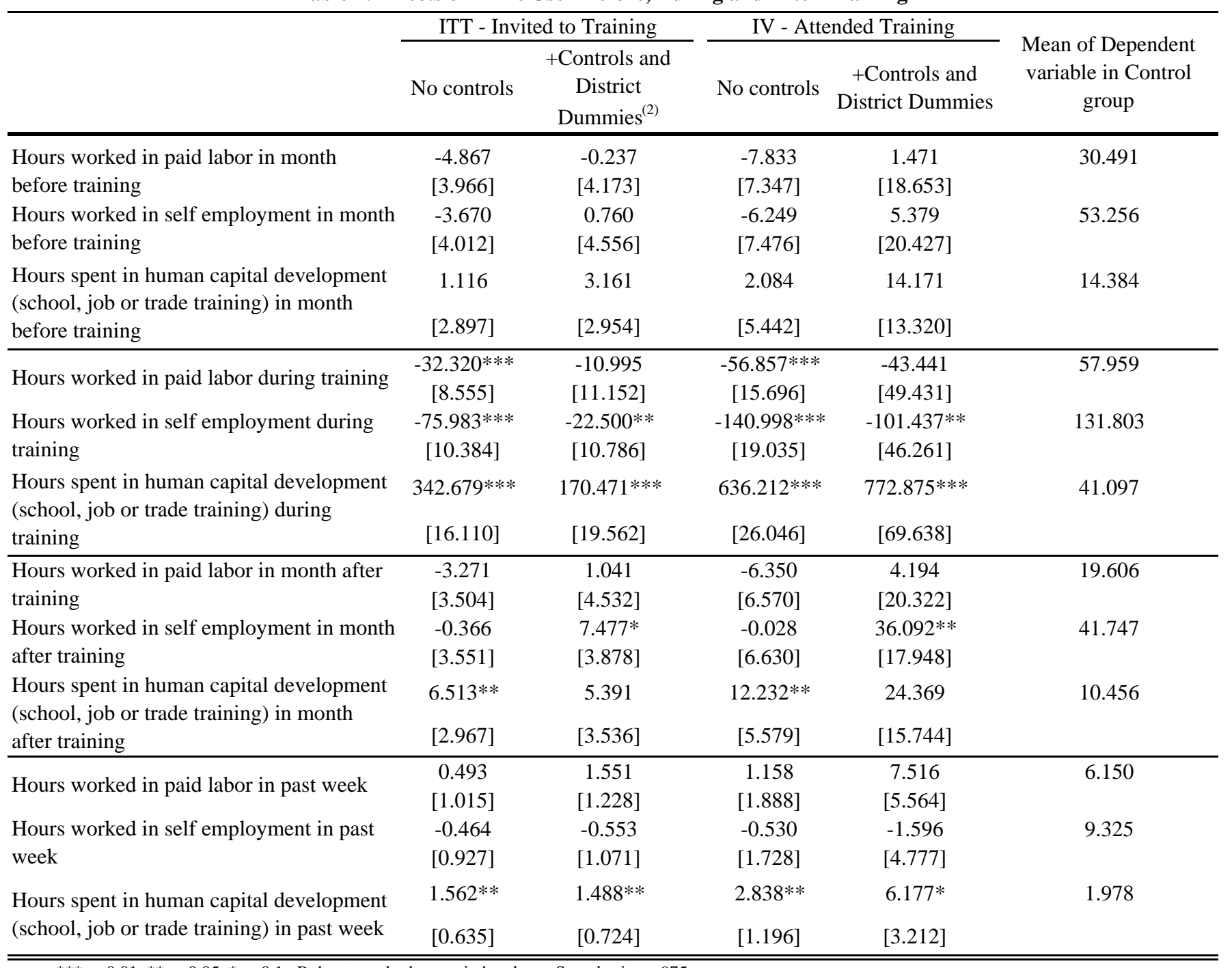

note: $* * * \mathrm{p}<0.01,{ }^{* *} \mathrm{p}<0.05,{ }^{*} \mathrm{p}<0.1$. Robust standard errors in brackets. Sample size $=975$.

${ }^{(1)}$ Dependent variables in first column. Coefficient is on the dummy variable Invited Training for ITT estimates and on Attended Training for IV estimates.

(2) Controls include: household size squared, number of children under 18 in hh, acres of land owned, age, gender, and dummy variables for married, currently a student, has friends/relatives near training site, and whether a hh member who was contributing to hh income died in the past 12 months. 
Table 8: Effects of training on Economic Outcomes ${ }^{(1)}$

\begin{tabular}{|c|c|c|c|c|c|}
\hline & \multicolumn{2}{|c|}{ ITT - Invited to Training } & \multicolumn{2}{|c|}{ IV - Attended Training } & \multirow[b]{2}{*}{$\begin{array}{c}\text { Mean of Dependent } \\
\text { variable in Control } \\
\text { group }\end{array}$} \\
\hline & No controls & $\begin{array}{c}+ \text { Controls and } \\
\text { District } \\
\text { Dummies }^{(2)}\end{array}$ & No controls & $\begin{array}{c}\text { +Controls and } \\
\text { District Dummies }\end{array}$ & \\
\hline Personal savings & $\begin{array}{c}-1,571.551^{*} \\
{[852.771]}\end{array}$ & $\begin{array}{c}-1,332.252 * \\
{[757.558]}\end{array}$ & $\begin{array}{l}-2,956.059 * \\
{[1,605.566]}\end{array}$ & $\begin{array}{l}-6,168.389 * \\
{[3,477.858]}\end{array}$ & $2,272.813$ \\
\hline Total earnings from work (last week) & $\begin{array}{l}-305.274 \\
{[266.610]}\end{array}$ & $\begin{array}{l}-195.244 \\
{[224.848]}\end{array}$ & $\begin{array}{l}-579.030 \\
{[504.245]}\end{array}$ & $\begin{array}{c}-898.751 \\
{[1,023.489]}\end{array}$ & 995.469 \\
\hline Started business during last 12 months & $\begin{array}{l}-0.047^{*} \\
{[0.026]}\end{array}$ & $\begin{array}{c}-0.071^{* *} \\
{[0.029]}\end{array}$ & $\begin{array}{l}-0.082 * \\
{[0.048]}\end{array}$ & $\begin{array}{c}-0.307 * * \\
{[0.133]}\end{array}$ & 0.188 \\
\hline Total monthly expenditure & $\begin{array}{l}-251.925 \\
{[366.602]}\end{array}$ & $\begin{array}{l}-616.123 \\
{[382.149]}\end{array}$ & $\begin{array}{c}-497.868 \\
{[688.935]}\end{array}$ & $\begin{array}{l}-2,852.917 \\
{[1,750.311]}\end{array}$ & 3,936.331 \\
\hline $\begin{array}{l}\text { Migrated permanently or temporarily, for } \\
\text { work, school or other }\end{array}$ & $\begin{array}{l}-0.061^{*} \\
{[0.031]}\end{array}$ & $\begin{array}{l}-0.069 * \\
{[0.036]}\end{array}$ & $\begin{array}{c}-0.120 * * \\
{[0.058]}\end{array}$ & $\begin{array}{c}-0.340 * * \\
{[0.167]}\end{array}$ & 0.319 \\
\hline
\end{tabular}

note: $* * * \mathrm{p}<0.01, * * \mathrm{p}<0.05, * \mathrm{p}<0.1$. Robust standard errors in brackets. Sample size $=975$.

${ }^{(1)}$ Dependent variables in first column. Coefficient is on the dummy variable Invited Training for ITT estimates and on Attended Training for IV estimates.

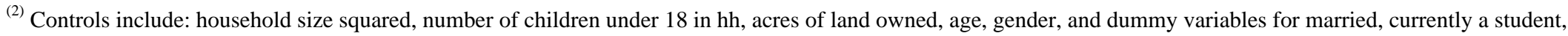
has friends/relatives near training site, and whether a hh member who was contributing to hh income died in the past 12 months. 
Table 9: Effects of training on Well-being ${ }^{(1)}$

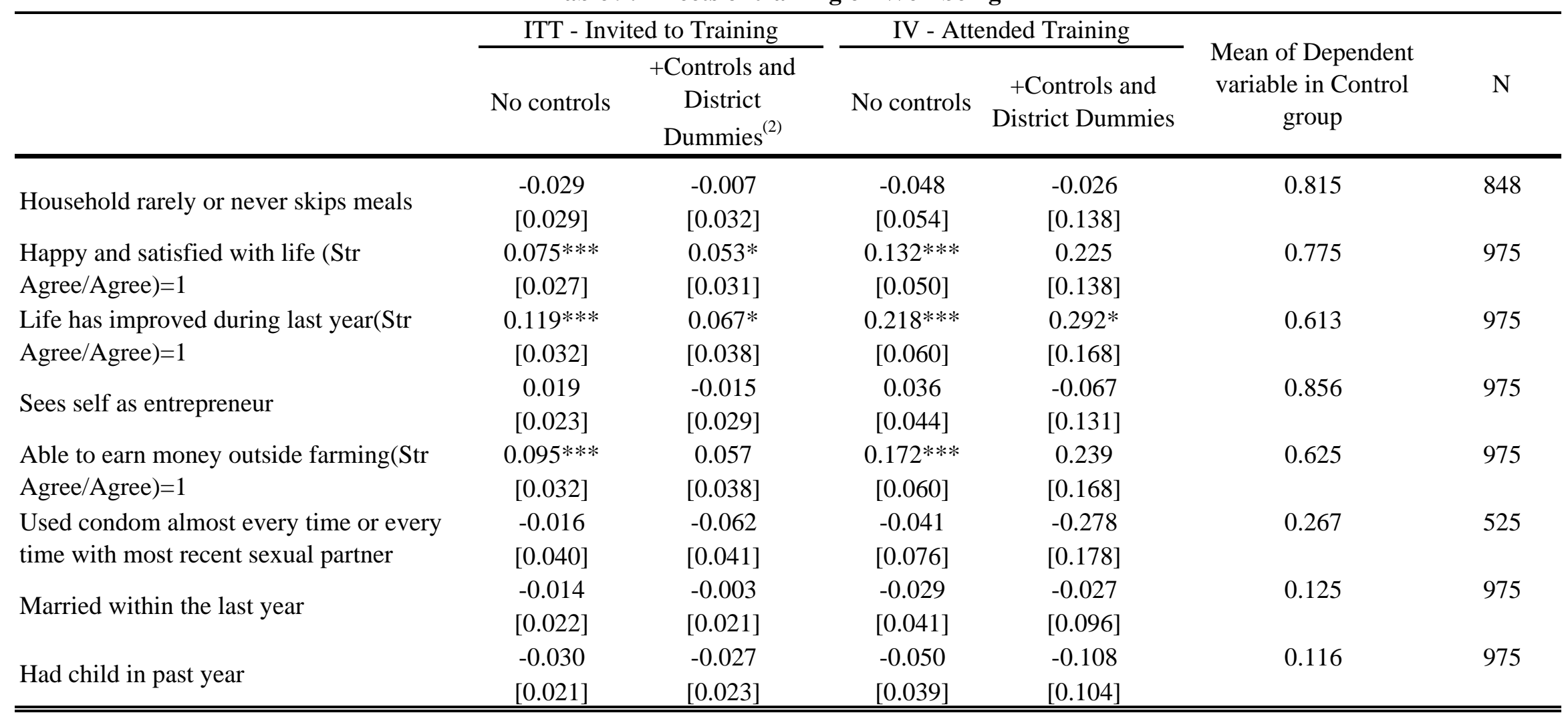

note: $* * * \mathrm{p}<0.01, * * \mathrm{p}<0.05, * \mathrm{p}<0.1$. Robust standard errors in brackets. Sample size $=975$, except for "Household rarely skips meals", for which there was a high number of missing responses, and "Used condom", for which many responses were "Not applicable" due to the fact that not all respondents were sexually active

${ }^{(1)}$ Dependent variables in first column. Coefficient is on the dummy variable Invited Training for ITT estimates and on Attended Training for IV estimates.

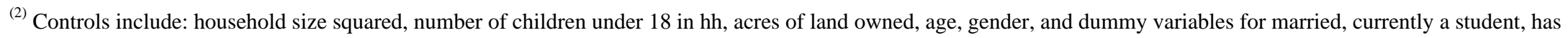
friends/relatives near training site, and whether a hh member who was contributing to hh income died in the past 12 months. 
Table 10: Effects of training, bv gender ${ }^{(1)}$

\begin{tabular}{|c|c|c|c|c|c|c|c|c|}
\hline & \multicolumn{3}{|c|}{ Men } & \multicolumn{3}{|c|}{ Women } & \multicolumn{2}{|c|}{$\begin{array}{l}\text { P-value of dif. btwn. } \\
\text { men and women }\end{array}$} \\
\hline & ITT & TOT & $\begin{array}{l}\text { Mean of dep. } \\
\text { var. in } \\
\text { control }\end{array}$ & ITT & TOT & $\begin{array}{l}\text { Mean of dep. } \\
\text { var. in } \\
\text { control }\end{array}$ & ITT & TOT \\
\hline $\begin{array}{l}\text { Skill in area/tradetoday (1:Poor/None } \\
10: \text { master craftsmen) }\end{array}$ & $\begin{array}{c}2.768 * * * \\
{[0.225]}\end{array}$ & $\begin{array}{c}5.061 * * * \\
{[0.390]}\end{array}$ & 2.580 & $\begin{array}{c}2.386 * * * \\
{[0.304]}\end{array}$ & $\begin{array}{c}4.553^{* * *} \\
{[0.540]}\end{array}$ & 2.575 & 0.313 & 0.446 \\
\hline $\begin{array}{l}\text { Knows calculate profits of a business } \\
\text { (today, 1-10) }\end{array}$ & $\begin{array}{c}1.654^{* * *} \\
{[0.259]}\end{array}$ & $\begin{array}{c}2.963 * * * \\
{[0.466]}\end{array}$ & 4.430 & $\begin{array}{c}1.582 * * * \\
{[0.346]}\end{array}$ & $\begin{array}{c}2.970 * * * \\
{[0.634]}\end{array}$ & 3.982 & 0.867 & 0.993 \\
\hline Knows how to start a business(today) $=1$ & $\begin{array}{c}0.244^{* * *} \\
{[0.041]}\end{array}$ & $\begin{array}{c}0.448^{* * *} \\
{[0.075]}\end{array}$ & 0.444 & $\begin{array}{c}0.233 * * * \\
{[0.056]}\end{array}$ & $\begin{array}{c}0.443 * * * \\
{[0.105]}\end{array}$ & 0.425 & 0.876 & 0.972 \\
\hline $\begin{array}{l}\text { Hours worked in paid labor during } \\
\text { training }\end{array}$ & $\begin{array}{c}-35.811^{* * *} \\
{[12.161]}\end{array}$ & $\begin{array}{c}-60.698^{* * *} \\
{[21.870]}\end{array}$ & 68.652 & $\begin{array}{c}-26.273^{* * *} \\
{[9.131]}\end{array}$ & $\begin{array}{c}-50.207 * * * \\
{[17.648]}\end{array}$ & 38.372 & 0.531 & 0.709 \\
\hline $\begin{array}{l}\text { Hours worked in self employment during } \\
\text { training }\end{array}$ & $\begin{array}{c}-96.271^{* * *} \\
{[14.004]}\end{array}$ & $\begin{array}{c}-174.867 * * * \\
{[25.378]}\end{array}$ & 153.633 & $\begin{array}{c}-38.891^{* * *} \\
{[13.632]}\end{array}$ & $\begin{array}{c}-76.347 * * * \\
{[25.562]}\end{array}$ & 91.814 & 0.003 & 0.006 \\
\hline $\begin{array}{l}\text { Hours spent in human capital } \\
\text { development (school, job or trade } \\
\text { training) during training }\end{array}$ & $\begin{array}{c}364.503 * * * \\
{[20.360]}\end{array}$ & $\begin{array}{c}666.042 * * * \\
{[33.035]}\end{array}$ & 33.952 & $\begin{array}{c}301.989 * * * \\
{[26.127]}\end{array}$ & $\begin{array}{c}578.051^{* * *} \\
{[41.610]}\end{array}$ & 54.186 & 0.059 & 0.098 \\
\hline $\begin{array}{l}\text { Hours worked in paid labor in month after } \\
\text { training }\end{array}$ & $\begin{array}{l}-2.768 \\
{[4.843]}\end{array}$ & $\begin{array}{c}-5.426 \\
{[8.936]}\end{array}$ & 23.502 & $\begin{array}{l}-4.405 \\
{[4.294]}\end{array}$ & $\begin{array}{c}-8.536 \\
{[8.292]}\end{array}$ & 12.469 & 0.800 & 0.799 \\
\hline $\begin{array}{l}\text { Hours worked in self employment in } \\
\text { month after training }\end{array}$ & $\begin{array}{l}-4.032 \\
{[4.798]}\end{array}$ & $\begin{array}{l}-7.262 \\
{[8.827]}\end{array}$ & 46.536 & $\begin{array}{l}6.296 \\
{[4.789]}\end{array}$ & $\begin{array}{l}13.730 \\
{[9.176]}\end{array}$ & 32.973 & 0.128 & 0.099 \\
\hline $\begin{array}{l}\text { Hours spent in human capital } \\
\text { development (school, job or trade } \\
\text { training) in month after training }\end{array}$ & $\begin{array}{c}11.446^{* * *} \\
{[3.245]}\end{array}$ & $\begin{array}{c}21.175^{* * *} \\
{[6.031]}\end{array}$ & 7.266 & $\begin{array}{l}-2.609 \\
{[5.906]}\end{array}$ & $\begin{array}{c}-5.060 \\
{[11.403]}\end{array}$ & 16.301 & 0.037 & 0.042 \\
\hline Hours worked in paid labor in past week & $\begin{array}{c}1.480 \\
{[1.340]}\end{array}$ & $\begin{array}{c}3.107 \\
{[2.454]}\end{array}$ & 6.903 & $\begin{array}{l}-1.368 \\
{[1.467]}\end{array}$ & $\begin{array}{c}-2.652 \\
{[2.836]}\end{array}$ & 4.770 & 0.152 & 0.125 \\
\hline $\begin{array}{l}\text { Hours worked in self employment in past } \\
\text { week }\end{array}$ & $\begin{array}{c}0.157 \\
{[1.179]}\end{array}$ & $\begin{array}{c}0.447 \\
{[2.177]}\end{array}$ & 9.879 & $\begin{array}{l}-1.639 \\
{[1.478]}\end{array}$ & $\begin{array}{l}-2.458 \\
{[2.801]}\end{array}$ & 8.310 & 0.342 & 0.413 \\
\hline $\begin{array}{l}\text { Hours spent in human capital } \\
\text { development (school, job or trade } \\
\text { training) in past week }\end{array}$ & $\begin{array}{c}2.342 * * * \\
{[0.793]}\end{array}$ & $\begin{array}{l}4.401^{* * *} \\
{[1.490]}\end{array}$ & 1.865 & $\begin{array}{c}0.113 \\
{[1.055]}\end{array}$ & $\begin{array}{l}-0.179 \\
{[2.002]}\end{array}$ & 2.186 & 0.091 & 0.066 \\
\hline Personal savings & $\begin{array}{l}-851.092 \\
{[940.754]}\end{array}$ & $\begin{array}{l}-1,576.879 \\
{[1,740.238]}\end{array}$ & $1,643.478$ & $\begin{array}{r}-2,895.749^{*} \\
{[1,690.151]}\end{array}$ & $\begin{array}{l}-5,608.688^{*} \\
{[3,286.013]}\end{array}$ & $3,425.664$ & 0.290 & 0.278 \\
\hline Total earnings from work (last week) & $\begin{array}{l}-192.645 \\
{[382.170]}\end{array}$ & $\begin{array}{l}-375.498 \\
{[713.202]}\end{array}$ & $1,043.116$ & $\begin{array}{l}-515.942 * \\
{[282.734]}\end{array}$ & $\begin{array}{l}-973.780^{*} \\
{[549.506]}\end{array}$ & 908.186 & 0.496 & 0.506 \\
\hline Started business during last 12 months & $\begin{array}{c}-0.007 \\
{[0.030]}\end{array}$ & $\begin{array}{c}-0.013 \\
{[0.056]}\end{array}$ & 0.155 & $\begin{array}{c}-0.120^{* * *} \\
{[0.046]}\end{array}$ & $\begin{array}{c}-0.215^{* *} \\
{[0.091]}\end{array}$ & 0.248 & 0.041 & 0.058 \\
\hline Total monthly expenditure & $\begin{array}{c}-21.396 \\
{[417.465]}\end{array}$ & $\begin{array}{c}-58.433 \\
{[770.657]}\end{array}$ & $3,957.976$ & $\begin{array}{l}-686.446 \\
{[703.468]}\end{array}$ & $\begin{array}{l}-1,364.300 \\
{[1,366.970]}\end{array}$ & $3,896.681$ & 0.416 & 0.405 \\
\hline $\begin{array}{l}\text { Migrated permanently or temporarily, for } \\
\text { work, school or other }\end{array}$ & $\begin{array}{c}-0.078^{* *} \\
{[0.038]}\end{array}$ & $\begin{array}{c}-0.144^{* *} \\
{[0.071]}\end{array}$ & 0.314 & $\begin{array}{l}-0.028 \\
{[0.053]}\end{array}$ & $\begin{array}{c}-0.072 \\
{[0.103]}\end{array}$ & 0.327 & 0.452 & 0.561 \\
\hline Household rarely or never skips meals & $\begin{array}{c}-0.043 \\
{[0.035]}\end{array}$ & $\begin{array}{l}-0.067 \\
{[0.063]}\end{array}$ & 0.823 & $\begin{array}{c}-0.002 \\
{[0.051]}\end{array}$ & $\begin{array}{c}-0.004 \\
{[0.103]}\end{array}$ & 0.800 & 0.514 & 0.598 \\
\hline $\begin{array}{l}\text { Happy and satisfied with life (Str } \\
\text { Agree/Agree) }=1\end{array}$ & $\begin{array}{c}0.082 * * \\
{[0.034]}\end{array}$ & $\begin{array}{c}0.142 * * \\
{[0.062]}\end{array}$ & 0.773 & $\begin{array}{c}0.063 \\
{[0.046]}\end{array}$ & $\begin{array}{c}0.113 \\
{[0.087]}\end{array}$ & 0.779 & 0.745 & 0.787 \\
\hline $\begin{array}{l}\text { Life has improved during last year(Str } \\
\text { Agree/Agree)=1 }\end{array}$ & $\begin{array}{c}0.146^{* * *} \\
{[0.040]}\end{array}$ & $\begin{array}{c}0.262 * * * \\
{[0.073]}\end{array}$ & 0.604 & $\begin{array}{c}0.068 \\
{[0.055]}\end{array}$ & $\begin{array}{c}0.132 \\
{[0.105]}\end{array}$ & 0.628 & 0.249 & 0.310 \\
\hline Sees self as entrepreneur & $\begin{array}{c}0.021 \\
{[0.027]}\end{array}$ & $\begin{array}{c}0.039 \\
{[0.050]}\end{array}$ & 0.874 & $\begin{array}{c}0.015 \\
{[0.043]}\end{array}$ & $\begin{array}{c}0.028 \\
{[0.083]}\end{array}$ & 0.823 & 0.900 & 0.912 \\
\hline $\begin{array}{l}\text { Able to earn money outside farming(Str } \\
\text { Agree/Agree) }=1\end{array}$ & $\begin{array}{c}0.103^{* * *} \\
{[0.039]}\end{array}$ & $\begin{array}{c}0.191^{* * *} \\
{[0.072]}\end{array}$ & 0.638 & $\begin{array}{c}0.078 \\
{[0.055]}\end{array}$ & $\begin{array}{c}0.134 \\
{[0.106]}\end{array}$ & 0.602 & 0.707 & 0.654 \\
\hline $\begin{array}{l}\text { Used condom almost every time or every } \\
\text { time with most recent sexual partner }\end{array}$ & $\begin{array}{r}-0.035 \\
{[0.053]}\end{array}$ & $\begin{array}{r}-0.081 \\
{[0.100]}\end{array}$ & 0.316 & $\begin{array}{c}0.018 \\
{[0.059]}\end{array}$ & $\begin{array}{c}0.032 \\
{[0.112]}\end{array}$ & 0.182 & 0.506 & 0.451 \\
\hline Had child in past year & $\begin{array}{l}-0.007 \\
{[0.022]}\end{array}$ & $\begin{array}{l}-0.004 \\
{[0.040]}\end{array}$ & 0.077 & $\begin{array}{l}-0.070^{*} \\
{[0.042]}\end{array}$ & $\begin{array}{l}-0.137^{*} \\
{[0.082]}\end{array}$ & 0.186 & 0.183 & 0.145 \\
\hline
\end{tabular}

note: $* * * \mathrm{p}<0.01,{ }^{* *} \mathrm{p}<0.05,{ }^{*} \mathrm{p}<0.1$. Robust standard errors in brackets. $\mathrm{N}=647$ for men, and $\mathrm{N}=347$ for women, except for 'condom use' (338 men and 201 women) and 'skips meals (582 men and 283 women).

${ }^{(1)}$ Dependent variables in first column. Coefficient is on the dummy variableInvited Training for ITT estimates and on Attended Training for IV 


\begin{tabular}{|c|c|c|c|}
\hline & Women & Men & P-value of Difference \\
\hline \multicolumn{4}{|l|}{ Trainees' Experiences } \\
\hline $\mathrm{N}$ & 460 & 791 & \\
\hline Months of training & 2.864 & 2.956 & 0.094 \\
\hline Missed no days of training & 0.452 & 0.533 & 0.042 \\
\hline Amount of stipend received for training per month (MWK) & $4,049.402$ & $4,028.777$ & 0.880 \\
\hline Stipend was sometimes insufficient to cover needs & 0.508 & 0.469 & 0.338 \\
\hline Received food or money from MC & 0.464 & 0.555 & 0.023 \\
\hline MC always attended training & 0.812 & 0.818 & 0.842 \\
\hline Tools were always available for practice & 0.680 & 0.737 & 0.115 \\
\hline Felt encouraged by MC & 0.916 & 0.933 & 0.420 \\
\hline Received paid work from MC following training & 0.012 & 0.039 & 0.048 \\
\hline \multicolumn{4}{|l|}{ Baseline Characteristics by Gender } \\
\hline $\mathrm{N}$ & 369 & 753 & \\
\hline \multicolumn{4}{|l|}{ Household Characteristics } \\
\hline Household size & 5.46 & 5.42 & 0.80 \\
\hline Number of adults & 2.50 & 2.79 & 0.00 \\
\hline Number of respondent's dependents (in or out of hh) & 1.01 & 0.75 & 0.00 \\
\hline Owns home $=1$ & 0.85 & 0.89 & 0.02 \\
\hline Number of acres of land owned & 1.76 & 1.91 & 0.33 \\
\hline \multicolumn{4}{|l|}{ Individual Characteristics } \\
\hline Age & 21.10 & 21.66 & 0.01 \\
\hline Head of household=1 & 0.12 & 0.20 & 0.00 \\
\hline Married or living with partner=1 & 0.13 & 0.18 & 0.02 \\
\hline Neither parents are alive (orphan) $=1$ & 0.31 & 0.38 & 0.03 \\
\hline Lives with at least one parent & 0.45 & 0.38 & 0.02 \\
\hline \multicolumn{4}{|l|}{ Educational Attainment } \\
\hline Completed primary & 0.06 & 0.05 & 0.58 \\
\hline Some secondary & 0.51 & 0.47 & 0.22 \\
\hline Completed Secondary & 0.19 & 0.25 & 0.03 \\
\hline Currently a student=1 & 0.09 & 0.11 & 0.38 \\
\hline Received vocational training $=1$ & 0.11 & 0.14 & 0.15 \\
\hline Previously started a business $=1$ & 0.36 & 0.34 & 0.56 \\
\hline \multicolumn{4}{|l|}{ Economic Variables } \\
\hline Annual personal income & $17,227.47$ & $26,820.08$ & 0.33 \\
\hline Number of loans in past 12 months & 0.37 & 0.37 & 0.97 \\
\hline Amount of loans in past 12 months (in MK) & $2,869.76$ & $2,370.47$ & 0.26 \\
\hline $\begin{array}{l}\text { Number of cash and in-kind grants from social programs in past } \\
6 \text { months }\end{array}$ & 0.64 & 0.70 & 0.21 \\
\hline $\begin{array}{l}\text { Amount of cash grants from social programs in past } 6 \text { months (in } \\
\text { MK) }\end{array}$ & $3,340.90$ & $7,717.29$ & 0.08 \\
\hline \multicolumn{4}{|l|}{ Time Use } \\
\hline Hours per year spent on agriculture or domestic chores & 764.58 & 425.26 & 0.00 \\
\hline Hours per year spent on paid labor & 105.74 & 203.79 & 0.00 \\
\hline Hours per year spent in own business & 48.22 & 51.59 & 0.80 \\
\hline Hours per year spent on other activities & 26.15 & 15.71 & 0.05 \\
\hline
\end{tabular}


Table 12: Effects of Dropping Out on Outcome Variables ${ }^{(1)}$

\begin{tabular}{|c|c|c|c|c|}
\hline & \multicolumn{2}{|c|}{$\begin{array}{c}\text { Dropped out (inc. } \\
\text { administrative dropouts) } \\
\end{array}$} & \multicolumn{2}{|c|}{$\begin{array}{l}\text { Dropped out (not inc. } \\
\text { administrative dropouts) }\end{array}$} \\
\hline & Men & Women & Men & Women \\
\hline \multirow{4}{*}{$\begin{array}{l}\text { Skill in area/tradetoday (1:Poor/None } \\
\text { 10:master craftsmen) } \\
\text { Knows calculate profits of a business (today, 1- } \\
\text { 10) }\end{array}$} & $-3.481 * * *$ & $-3.775 * * *$ & $-2.432 * * *$ & $-3.006 * * *$ \\
\hline & {$[0.248]$} & {$[0.310]$} & {$[0.394]$} & {$[0.478]$} \\
\hline & $-2.541 * * *$ & $-2.800 * * *$ & $-1.832 * * *$ & $-2.597 * * *$ \\
\hline & {$[0.266]$} & {$[0.351]$} & {$[0.390]$} & {$[0.476]$} \\
\hline \multirow{2}{*}{ Knows how to start a business(today) $=1$} & $-0.269 * * *$ & $-0.437 * * *$ & $-0.155^{* *}$ & $-0.357 * * *$ \\
\hline & {$[0.044]$} & {$[0.057]$} & {$[0.066]$} & {$[0.085]$} \\
\hline \multirow{2}{*}{ Hours worked in paid labor in past week } & $4.211^{* *}$ & -0.489 & 4.396 & 0.416 \\
\hline & [1.734] & [1.411] & [3.027] & [1.988] \\
\hline \multirow{2}{*}{ Hours worked in self employment in past week } & -1.985 & -1.310 & -1.588 & -0.438 \\
\hline & [1.273] & [1.502] & [2.002] & [1.918] \\
\hline \multirow{2}{*}{$\begin{array}{l}\text { Hours spent in human capital development } \\
\text { (school, job or trade training) in past week }\end{array}$} & -0.189 & -0.862 & 1.892 & $-1.712 *$ \\
\hline & [1.175] & [1.073] & [2.162] & [1.014] \\
\hline \multirow{2}{*}{ Personal savings } & 75.041 & -46.098 & 183.850 & -246.312 \\
\hline & [308.938] & [250.366] & [392.220] & [252.337] \\
\hline \multirow{2}{*}{ Total earnings from work (last week) } & 113.933 & -104.544 & 19.920 & 74.925 \\
\hline & {$[175.531]$} & [152.583] & [247.188] & [293.423] \\
\hline \multirow{2}{*}{ Started business during last 12 months } & 0.010 & -0.066 & 0.054 & -0.037 \\
\hline & {$[0.035]$} & [0.043] & {$[0.056]$} & {$[0.061]$} \\
\hline \multirow{2}{*}{ Total monthly expenditure } & -493.182 & $-1,091.667 *$ & -841.640 & -929.478 \\
\hline & [458.018] & [659.644] & [596.657] & [840.741] \\
\hline \multirow{2}{*}{$\begin{array}{l}\text { Migrated permanently or temporarily, for } \\
\text { work, school or other }\end{array}$} & 0.011 & 0.045 & $0.135 * *$ & 0.023 \\
\hline & [0.041] & {$[0.060]$} & {$[0.067]$} & {$[0.082]$} \\
\hline \multirow{2}{*}{ Household rarely or never skips meals } & 0.018 & 0.056 & -0.002 & 0.018 \\
\hline & {$[0.042]$} & [0.058] & [0.063] & [0.083] \\
\hline Happy and satisfied with life (Str & $-0.085^{* *}$ & -0.067 & $-0.109 *$ & -0.019 \\
\hline Agree/Agree) $=1$ & {$[0.035]$} & {$[0.048]$} & {$[0.056]$} & [0.063] \\
\hline Life has improved during last year(Str & $-0.204 * * *$ & $-0.151 * *$ & $-0.218 * * *$ & -0.103 \\
\hline Agree/Agree)=1 & [0.042] & {$[0.061]$} & [0.067] & {$[0.084]$} \\
\hline \multirow{2}{*}{ Sees self as entrepreneur } & $-0.099 * * *$ & $-0.179 * * *$ & $-0.122 * *$ & $-0.213 * * *$ \\
\hline & {$[0.031]$} & [0.049] & {$[0.052]$} & {$[0.076]$} \\
\hline Able to earn money outside farming(Str & $-0.121 * * *$ & $-0.153^{* *}$ & $-0.139 * *$ & $-0.209 * *$ \\
\hline Agree/Agree)=1 & [0.043] & {$[0.061]$} & {$[0.066]$} & {$[0.088]$} \\
\hline \multirow{2}{*}{$\begin{array}{l}\text { Used condom almost every time or every time } \\
\text { with most recent sexual partner }\end{array}$} & -0.005 & -0.021 & 0.035 & -0.051 \\
\hline & [0.061] & {$[0.070]$} & [0.089] & [0.089] \\
\hline \multirow{2}{*}{ Married within the last year } & 0.008 & 0.056 & 0.006 & 0.035 \\
\hline & [0.029] & [0.046] & {$[0.043]$} & {$[0.062]$} \\
\hline \multirow{2}{*}{ Had child in past year } & 0.016 & 0.053 & 0.052 & 0.075 \\
\hline & [0.025] & [0.043] & [0.044] & {$[0.065]$} \\
\hline
\end{tabular}

note: ${ }^{* * *} \mathrm{p}<0.01,{ }^{* *} \mathrm{p}<0.05,{ }^{*} \mathrm{p}<0.1$. Robust standard errors in brackets. When including administrative dropouts, $\mathrm{N}=421$ for men, 230 for women, except for 'skips meals' (381/189) and 'condom' (214/132). Not including administrative dropouts, N=298 for men, 164 for women, except for 'skips meals' (276/131) and 'condom' (152/94).

${ }^{(1)}$ Dependent variables in first column. Coefficient is on the dummy variable Droppped Out 
Table 13: Effects of training: Lower bounds Assuming Treatment group Attriters would be like (matched) Controls ${ }^{(1)}$

\begin{tabular}{|c|c|c|c|c|c|c|c|c|}
\hline & \multicolumn{3}{|c|}{ Men } & \multicolumn{3}{|c|}{ Women } & \multicolumn{2}{|c|}{$\begin{array}{l}\text { P-value of dif. btwn. } \\
\text { men and women }\end{array}$} \\
\hline & ITT & TOT & $\begin{array}{l}\text { Mean of dep. } \\
\text { var. in } \\
\text { control }\end{array}$ & ITT & TOT & $\begin{array}{l}\text { Mean of dep. } \\
\text { var. in } \\
\text { control }\end{array}$ & ITT & TOT \\
\hline \multirow{2}{*}{$\begin{array}{l}\text { Skill in area/tradetoday (1:Poor/None } \\
\text { 10:master craftsmen) }\end{array}$} & $1.849 * * *$ & $5.564 * * *$ & 2.400 & $1.625 * * *$ & $4.721^{* * *}$ & 2.282 & 0.475 & 0.258 \\
\hline & 0.184 & 0.420 & & 0.254 & 0.616 & & & \\
\hline \multirow{2}{*}{$\begin{array}{l}\text { Knows calculate profits of a business } \\
\text { (today, 1-10) }\end{array}$} & $1.101^{* * *}$ & $3.490 * * *$ & 4.258 & $1.063 * * *$ & $3.631 * * *$ & 3.981 & 0.913 & 0.880 \\
\hline & 0.212 & 0.542 & & 0.282 & 0.757 & & & \\
\hline \multirow{2}{*}{ Knows how to start a business(today) $=1$} & $0.165^{* * *}$ & $0.572 * * *$ & 0.456 & $0.095^{* *}$ & $0.416^{* * *}$ & 0.480 & 0.219 & 0.308 \\
\hline & 0.033 & 0.087 & & 0.046 & 0.127 & & & \\
\hline \multirow{2}{*}{$\begin{array}{l}\text { Hours worked in paid labor during } \\
\text { training }\end{array}$} & $-18.605^{* *}$ & $-65.969 * * *$ & 66.415 & -12.539 & $-41.093^{*}$ & 48.788 & 0.625 & 0.444 \\
\hline & 8.852 & 23.171 & & 8.693 & 22.763 & & & \\
\hline \multirow{2}{*}{$\begin{array}{l}\text { Hours worked in self employment during } \\
\text { training }\end{array}$} & $-61.396 * * *$ & $-184.644 * * *$ & 142.471 & $-18.963 *$ & $-52.561 *$ & 93.854 & 0.009 & 0.002 \\
\hline & 11.594 & 30.925 & & 11.245 & 29.555 & & & \\
\hline \multirow{2}{*}{$\begin{array}{l}\text { Hours spent in human capital } \\
\text { development (school, job or trade } \\
\text { training) during training }\end{array}$} & $222.473^{* * *}$ & $675.637 * * *$ & 54.490 & $202.170 * * *$ & $585.265^{* * *}$ & 57.642 & 0.509 & 0.150 \\
\hline & 18.623 & 36.331 & & 24.516 & 51.195 & & & \\
\hline \multirow{2}{*}{$\begin{array}{l}\text { Hours worked in paid labor in month } \\
\text { after training }\end{array}$} & -1.500 & -6.355 & 23.756 & -0.965 & 0.384 & 15.144 & 0.911 & 0.592 \\
\hline & 3.599 & 9.799 & & 3.123 & 7.903 & & & \\
\hline \multirow{2}{*}{$\begin{array}{l}\text { Hours worked in self employment in } \\
\text { month after training }\end{array}$} & -0.774 & -6.081 & 43.482 & 0.231 & 7.821 & 36.263 & 0.858 & 0.355 \\
\hline & 3.865 & 10.435 & & 4.097 & 10.838 & & & \\
\hline \multirow{2}{*}{$\begin{array}{l}\text { Hours spent in human capital } \\
\text { development (school, job or trade } \\
\text { training) in month after training }\end{array}$} & $7.246 * * *$ & $22.281 * * *$ & 6.331 & -0.935 & -7.831 & 11.288 & 0.097 & 0.038 \\
\hline & 2.415 & 6.605 & & 4.300 & 12.898 & & & \\
\hline \multirow{2}{*}{ Hours worked in paid labor in past week } & 0.845 & 3.358 & 7.526 & -2.003 & -3.673 & 6.861 & 0.089 & 0.127 \\
\hline & 1.083 & 2.818 & & 1.277 & 3.647 & & & \\
\hline \multirow{2}{*}{$\begin{array}{l}\text { Hours worked in self employment in past } \\
\text { week }\end{array}$} & -0.597 & -1.352 & 9.502 & -1.349 & -2.595 & 8.519 & 0.621 & 0.774 \\
\hline & 0.930 & 2.501 & & 1.206 & 3.542 & & & \\
\hline \multirow{2}{*}{$\begin{array}{l}\text { Hours spent in human capital } \\
\text { development (school, job or trade } \\
\text { training) in past week }\end{array}$} & $1.279 * *$ & $4.967 * * *$ & 1.924 & -0.108 & -0.391 & 2.031 & 0.198 & 0.091 \\
\hline & 0.570 & 1.564 & & 0.914 & 2.754 & & & \\
\hline \multirow{2}{*}{ Personal savings } & $1,222.038 * * *$ & -269.996 & $1,986.008$ & $-3,601.396 * *$ & $-8,926.101^{*}$ & $6,591.695$ & 0.008 & 0.093 \\
\hline & 463.474 & 440.375 & & $1,759.411$ & $5,137.113$ & & & \\
\hline \multirow{2}{*}{ Total earnings from work (last week) } & 84.803 & 153.350 & 807.142 & -216.937 & -310.460 & 832.331 & 0.082 & 0.324 \\
\hline & 104.204 & 272.517 & & 138.817 & 383.253 & & & \\
\hline \multirow{2}{*}{ Started business during last 12 months } & 0.001 & -0.055 & 0.198 & $-0.133^{* * *}$ & $-0.269 * *$ & 0.318 & 0.007 & 0.104 \\
\hline & 0.026 & 0.064 & & 0.042 & 0.115 & & & \\
\hline \multirow{2}{*}{ Total monthly expenditure } & 170.844 & 368.791 & $3,940.671$ & -84.954 & 400.696 & 4,069.229 & 0.666 & 0.984 \\
\hline & 291.677 & 750.093 & & 515.752 & $1,448.556$ & & & \\
\hline \multirow{2}{*}{$\begin{array}{l}\text { Migrated permanently or temporarily, for } \\
\text { work, school or other }\end{array}$} & $-0.066^{* *}$ & $-0.142 *$ & 0.354 & $-0.090 * *$ & -0.156 & 0.395 & 0.664 & 0.926 \\
\hline & 0.031 & 0.081 & & 0.045 & 0.127 & & & \\
\hline \multirow{4}{*}{$\begin{array}{l}\text { Happy and satisfied with life (Str } \\
\text { Agree/Agree)=1 } \\
\text { Life has improved during last year(Str } \\
\text { Agree/Agree)=1 }\end{array}$} & 0.022 & 0.068 & 0.801 & 0.051 & $0.184^{*}$ & 0.786 & 0.520 & 0.363 \\
\hline & 0.026 & 0.069 & & 0.037 & 0.107 & & & \\
\hline & 0.048 & $0.208 * *$ & 0.626 & 0.037 & 0.158 & 0.610 & 0.841 & 0.750 \\
\hline & 0.031 & 0.084 & & 0.045 & 0.130 & & & \\
\hline Sees solf as entrenreneur & 0.003 & 0.076 & 0.852 & 0.015 & 0.082 & 0.785 & 0.773 & 0.958 \\
\hline & 0.023 & 0.060 & & 0.038 & 0.109 & & & \\
\hline Able to earn money outside farming(Str & 0.035 & $0.202 * *$ & 0.635 & $0.132 * * *$ & $0.296 * *$ & 0.536 & 0.088 & 0.543 \\
\hline Agree/Agree)=1 & 0.032 & 0.084 & & 0.047 & 0.131 & & & \\
\hline Had child in nast vear & -0.010 & -0.022 & 0.077 & 0.010 & -0.011 & 0.107 & 0.591 & 0.916 \\
\hline & 0.018 & 0.048 & & 0.032 & 0.094 & & & \\
\hline
\end{tabular}

note: $* * * \mathrm{p}<0.01,{ }^{* *} \mathrm{p}<0.05,{ }^{*} \mathrm{p}<0.1$. Robust standard errors in brackets. $\mathrm{N}=746$ for men, and $\mathrm{N}=368$ for women.

${ }^{(1)}$ Dependent variables in first column. Coefficient is on the dummy variableInvited Training for ITT estimates and on Attended Training for IV estimates. 


\begin{tabular}{|c|c|c|c|c|c|c|}
\hline & Control & $\begin{array}{l}\text { Dropped out (inc. } \\
\text { administrative } \\
\text { dropouts) }\end{array}$ & $\begin{array}{l}\text { P-value of } \\
\text { difference }\end{array}$ & Control & $\begin{array}{l}\text { Dropped out (not } \\
\text { inc. administrative } \\
\text { dropouts) }\end{array}$ & $\begin{array}{l}\text { P-value of } \\
\text { difference }\end{array}$ \\
\hline $\mathrm{N}$ & 328 & 307 & & 328 & 106 & \\
\hline \multicolumn{7}{|l|}{ Household Characteristics } \\
\hline Household size & 4.93 & 4.84 & 0.62 & 4.93 & 4.84 & 0.71 \\
\hline Number of adults & 2.84 & 2.72 & 0.25 & 2.84 & 2.73 & 0.44 \\
\hline $\begin{array}{l}\text { Number of respondent's } \\
\text { dependents (in or out of hh) }\end{array}$ & 1.35 & 1.65 & 0.06 & 1.35 & 1.66 & 0.15 \\
\hline Owns home $=1$ & 0.84 & 0.83 & 0.70 & 0.84 & 0.81 & 0.45 \\
\hline \multicolumn{7}{|l|}{ Individual Characteristics } \\
\hline Gender:Male=1 & 0.64 & 0.64 & 0.83 & 0.64 & 0.59 & 0.36 \\
\hline Age & 22.00 & 21.29 & 0.01 & 22.00 & 21.35 & 0.08 \\
\hline Head of household=1 & 0.23 & 0.24 & 0.84 & 0.23 & 0.26 & 0.50 \\
\hline Married or living with partner $=1$ & 0.29 & 0.27 & 0.65 & 0.29 & 0.27 & 0.75 \\
\hline $\begin{array}{l}\text { Neither parents are alive } \\
\text { (orphan)=1 } \\
\text { Educational Attainment }\end{array}$ & 0.45 & 0.42 & 0.50 & 0.45 & 0.38 & 0.21 \\
\hline All primary & 0.05 & 0.04 & 0.35 & 0.05 & 0.02 & 0.12 \\
\hline Some secondary & 0.55 & 0.53 & 0.74 & 0.55 & 0.55 & 0.98 \\
\hline All secondary & 0.15 & 0.16 & 0.63 & 0.15 & 0.11 & 0.39 \\
\hline Currently a student=1 & 0.11 & 0.15 & 0.13 & 0.11 & 0.14 & 0.43 \\
\hline Received vocational training=1 & 0.11 & 0.07 & 0.13 & 0.11 & 0.08 & 0.47 \\
\hline \multicolumn{7}{|l|}{ Economic Variables } \\
\hline Previously started a business=1 & 0.37 & 0.31 & 0.14 & 0.37 & 0.31 & 0.31 \\
\hline $\begin{array}{l}\text { Worked for wage in past } 12 \\
\text { months }=1\end{array}$ & 0.22 & 0.18 & 0.28 & 0.22 & 0.21 & 0.85 \\
\hline Personal savings & $2,266.16$ & 731.11 & 0.08 & $2,266.16$ & 720.75 & 0.29 \\
\hline $\begin{array}{l}\text { Number of loans in past } 12 \\
\text { months }\end{array}$ & 0.35 & 0.36 & 0.79 & 0.35 & 0.41 & 0.39 \\
\hline $\begin{array}{l}\text { Amount of loans in past } 12 \\
\text { months (in MK) }\end{array}$ & $3,548.50$ & $2,710.38$ & 0.35 & $3,548.50$ & $2,978.21$ & 0.66 \\
\hline $\begin{array}{l}\text { Expenditure on food as percent } \\
\text { of total }\end{array}$ & 0.47 & 0.47 & 0.82 & 0.47 & 0.47 & 0.97 \\
\hline \multicolumn{7}{|l|}{$\begin{array}{l}\text { In the past } 12 \text { months, has } \\
\text { anyone in your hh had to skip } \\
\text { meals? }\end{array}$} \\
\hline No & 0.47 & 0.50 & 0.53 & 0.47 & 0.50 & 0.68 \\
\hline Yes, but infrequently & 0.34 & 0.31 & 0.44 & 0.34 & 0.28 & 0.33 \\
\hline Yes, about once a month & 0.10 & 0.08 & 0.45 & 0.10 & 0.10 & 0.98 \\
\hline Yes, more than once month & 0.09 & 0.11 & 0.39 & 0.09 & 0.12 & 0.41 \\
\hline \multicolumn{7}{|l|}{ Migration } \\
\hline $\begin{array}{l}\text { Migration episodes in past } 12 \\
\text { months }\end{array}$ & 0.28 & 0.20 & 0.04 & 0.28 & 0.26 & 0.78 \\
\hline $\begin{array}{l}\text { Average duration of migration } \\
\text { episode }\end{array}$ & 8.61 & 12.93 & 0.17 & 8.61 & 12.67 & 0.31 \\
\hline $\begin{array}{l}\text { Number of migration episodes } \\
\text { for work in past } 12 \text { months }\end{array}$ & 0.08 & 0.05 & 0.12 & 0.08 & 0.07 & 0.63 \\
\hline
\end{tabular}

